\title{
Problemer i Slesvigs kirkeliv i årene nærmest efter 1864
}

\author{
Af Asger Nybolm.
}

Danmarks nederlag i krigen 1864 ramte de dansksindede slesvigere hårdt. Stemningen imod dem stod at læse $\mathrm{i} \gg$ Flensburger Tageblatt " allerede i London-konferencens dage (21. juni 1864): "Den politiske uvilje i Nordslesvig mod Tyskland kan kun være en undtagelsestilstand, frembragt af dansk agitation og korruption. Ved hele udviklingens gang er det aldeles sikkert, at i rolig, uforstyrret gang vil den lavere danske kultur blive fortrængt af den højere tyske«.

Men også de slesvig-holstensk-sindede, der vel var Preussen taknemmelige for løsrivelsen fra Danmark, kom snart til at føle sig skuffede og desorienterede. Med begejstring havde de hilst den aurgustenborgske hertug Friedrich, da han den 16. november 1863 dagen efter Frederik 7.s død - proklamerede, at han ville tiltræde regeringen over hertugdømmerne, idet han erklærede: "min ret er eders redning " og samtidig forpligtede sig til at overholde den grundlov for hertugdømmerne, som den slesvig-holstenske landsforsamling havde vedtaget den 15. september 1848. En god måned senere, den 22. december, mødtes en stor folkeforsamling i Elmshorn, "som vore forfædre samledes på åben mark «. Dér erklærede man under begejstret tilslutning, at »ingen anden fyrste skal herske over os end vor retmæssige hertug "Friedrich der Achte « af SlesvigHolsten«. Det såkaldte "liberale landsparti«s program: et selvstændigt Slesvig-Holsten under huset Augustenborg og med grundloven af 1848 var proklameret. En "næsten religiøs begejstring " for det augustenborgske dynastis ret og folkets nationale ret havde grebet befolkningen. ${ }^{1}$

På baggrund af denne begejstring føltes det bittert, at de sejrende parter, Preussen og Østrig, efter krigen holdt hertugen ude af bil- 
ledet. Foreløbig blev Slesvig og Holsten stillet under henholdsvis preussisk og østrigsk styrelse. Hertugdømmernes fremtidige skæbne lå $\mathrm{i}$ det uvisse.

Forholdet mellem de to sejrherrer blev mere og mere spæendt. Østrig kunne ikke ønske hertugdømmerne indlemmet i Preussen. Det ville styrke det rivaliserende Preussens magtstilling. Derfor så $\varnothing_{\text {strig }}$ gerne, at Slesvig-Holsten blev et selvstændigt augustenborgsk hertugdømme. Preussen derimod ønskede ikke en ny lillestat optaget i det tyske forbund. Bismarck stillede sig derfor afvisende overfor augustenborgernes arvekrav. I Slesvig forbød Preussen alle tilkendegivelser til fordel for hertugen.

I det liberale parti $\mathrm{i}$ hertugdømmerne vendte harmen sig derfor mod Preussen. Det blev sagt, at man nu efter danskertiden blot havde fået en anden fjende, og at ingen pris var for hoj for at holde sig Preussen fra livet.

Men ikke alle tænkte således. I det såkaldte "nationale" parti havde man allerede nogle år før krigen set det som målet, at hertugdømmerne blev tilsluttet et centraliseret Tyskland under Preussens førerskab. Dér betragtede man Preussen som "Tysklands sværd «, som et »værn for den protestantiske frihed .

I 1866 førte spændingen mellem Preussen og Østrig til krig. Allerede den 7. juni - inden krigens udbrud - besatte preussiske tropper Holsten og de østrigske tropper drog bort. Preussisk anneksion af begge hertugdømmer var at vente. "Nationalzeitung " skrev (24/7 1866), at slesvig-holstenerne skulle lære $\gg d e n$ strenge preussiske tugt $\ll$.

Preussens sejre bragte en vis forskydning $i$ stemningen $i$ hertugdømmerne til fordel for de $n$ nationale $\ll$. Men da freden blev sluttet i Prag (23. aug. 1866), vakte dens $\$ 5$ misstemning mod Preussen. Efter den skulle de nordlige distrikter i Slesvig afstås til Danmark, hvis befolkningen ved en fri afstemning tilkendegav ønsket derom. Lige så meget som dansksindede slesvigere satte deres håb til denne paragraf, lige så skuffet erklærede man fra slesvig-holstensk side: "Som et Damokles-sværd hænger Nordslesvigs afståelse over slesvigholstenernes hoveder «.

Efter krigen annekterede Preussen begge hertugdømmer. Det føltes af de liberale som et retsbrud. Da hertugdømmerne skulle vælge representanter til den konstituerende rigsdag i det nyoprettede nord- 
tyske forbund, fik det liberale oppositionsparti 70.000, de »nationale « preusservenner kun 30.000 stemmer. Bortset fra to danske kandidater, der valgtes i Nordslesvig (Krüger og Ahlmann), fik de liberale alle deres kandidater valgt.

Med hensyn til hertugdømmernes indre forhold blev det lovet befolkningen, at hertugdømmernes "berettigede særpræg « ville blive respekteret, forsåvidt de kunne bestå uden skade for statens enhed og interesser. Mange nyordninger blev gennemført, nogle uden at befolkningen blev hørt, adskillige mødt med uvilje.

Forvaltningen af den slesvig-holstenske statskapital blev overdraget generalstatskassen i Berlin. Grundlaget for den provinsielle selvforvaltning føltes dermed undergravet. Ved en ny retsplejeordning blev den øverste appelinstans flyttet fra hertugdømmerne til Berlin. Det blev betragtet som en undervurdering af nytten ved at have øverste retsinstans samme sted som universitetet. Der blev indført tre-årig militærtjeneste. Ingen kunne som tidligere købe sig fri. Ditmarsken og vesterhavsøerne var nu ikke længere fritaget for militærtjeneste. Det bevirkede, at mange, særlig fra vesterhavsøerne, udvandrede for at unddrage sig militærtjenesten. En ny skatteordning. der nedsatte de gamle grundskatter på landet og bygningsskatter $\mathrm{i}$ byerne, men samtidig indførte indkomst- og erhvervsskatter, blev af mange følt som uretfxrdig. En lov om erhvervsfrihed hindrede lavene $i$ at udelukke nogen fra et erhverv. Men arbejderne ønskede ikke at komme ud af den gamle tryghed under den beskyttende lavsordning. Pastvangen blev ophævet. Det medførte tilstrømning af ubemidlede udefra, der påførte arbejderne konkurrence og kommunerne øget forsørgerpligt.

Meget af det nye føltes som en krænkelse af hertugdømmernes »berettigede sxrpræg " og uddybede uviljen mod det Preussen, der havde nægtet hertugdømmerne selvstændighed under den augustenborgske arveherre. De augustenborgske sympatier var stærkest repræsenteret mod syd. I det nordlige Slesvig var stemningen for Preussen mere udtalt som et modtræk mod det stærke indslag af dansk sindelag.

Men trods alt blev det de liberale mere og mere klart, at grundlaget for Tysklands enhed og frihed måtte være anerkendelsen af den ordning, som Preussen havde skabt. Partiet slog efterhånden ind på forsoningspolitik med Preussen. Ved begyndelsen af året 1870 
skal det kun have været en lille kreds, hvor augustenborgske sympatier og onsket om slesvig-holstensk selvstændighed var levende. ${ }^{2}$ Krigen mod Frankrig blev officielt $\mathrm{i}$ hertugdømmernes tysksindede befolkning hilst med en lignende begejstring som $i$ det øvrige Tyskland. "Slesvig-Holsten vil i glad offervillighed kappes med de gamle provinser, « hed det $i$ en adresse fra forskellige partier.

De officielle tilkendegivelser kan dog ikke tages som fuldgyldigt udtryk for befolkningens stemning under og efter krigen og efter kejserdømmets oprettelse. Der var handlet med hertugdømmerne hen over hovedet på befolkningen. Begrebet »Musspreussen « vidner om, at befolkningen var blevet preussere mere af nødvendighed end af egen fri vilje.

I den følgende tid så den preussiske regering det da også som sin opgave ikke blot at modvirke den danske bevægelse i Nordslesvig og at hindre socialdemokratiets udbredelse, men også at bekæmpe "Augustenburgertum . $^{3}$ Omvendt søgte socialdemokraterne at høste fordel af misfornøjelsen blandt tilhængere af Augustenborg og blandt de dansksindede.

Af disse tre oppositionspartier får de dansksindede og socialdemokraterne megen omtale i præsternes visitatsindberetninger. Den specielle slesvig-holstenske uvilje mod Preussen omtales derimod sjxldent. Det er vel sandsynligt, at der sigtes dertil i de følgende par indberetninger.

Fra Læk beretter præsten 1872, at skønt menigheden $i$ det store og hele $\mathrm{i}$ politisk henseende føler sig som tysk, så ville man tage meget fejl, hvis man tror, at der var stor begejstring for de store begivenheder i 1870 og 1871. Det har endnu ikke været befolkningen muligt at hæve sig over den provinsielle particularisme - selv om det dog ikke kan forties, at der dér i sognet også er blevet plantet nogle fredsege, og at præsten ved den lejlighed, særlig i Stadum, kunne glæde sig ved at iagttage en mere ideel rettet tysk fædrelandskærlighed.

Præsten i Bannesdorf på Fehmern skriver 1875, at der er stor afstand mellem de rige, navnlig forsåvidt de bærer gamle fehmerske navne, og de mindre bemidlede. Det kan ved valgene udarte til åben opposition, hvor feltråbet fra den ene side er $»$ Hie Welf « og fra den anden side "Hie Waiblingen «. Dette kan næppe forstås anderledes, end at ved valget 1874 har det førstnævnte valgsprog været det 
antipreussiske partis, og det sidstnæunte de preusservenliges. ${ }^{4}$

Der kan ikke bygges meget på dette par udtalelser. Der kan på den anden side ikke sluttes meget ud fra præsternes gennemgående tavshed om specielt slesvig-holstenske og augustenborgske sympatier og deraf følgende antipreussiske stemninger. Det spørgsmål kunne ikke væsentlig berøre kirkelivet. Men man kan derimod konstatere, at de $x$ ndrede ydre vilkår stillede kirken overfor en helt ny tid med nye tidsstrømninger, som ikke var de kirkeligt sindede velkomne.

De politiske begivenheder greb dybt ind i kirkelivet i Slesvig og rejste nye problemer, ikke blot for dansksindede, men også for slesvig-holstensksindede.

Allerede et par uger efter Danevirkes rømning ophævede den preussiske civilkommissær i Slesvig sprogreskripterne. Næsten alle de sogne i Mellemslesvig, hvor man fra dansk side havde indført dansk sprog i skolerne og danske gudstjenester hver anden søndag, fik atter tysk sprog i skole og kirke. Mange af de præster, der nordfra var kommet til Slesvig, måtte fortrække.

I det hele holdt det hårdt for dansksindede præster at fortsætte under de nye vilkår. Mange måtte atter drage nordpå, først i 1864, siden i 1867, da de ikke kunne få sig til at aflægge ed til den preussiske konge, og endelig i 1870, da de ikke ville bede for tysk sejr under den fransk-tyske krig.

Det kunne være vanskeligt nok at skaffe erstatning for de præster, der drog nordpå. Nogle af de præster, der havde forladt Slesvig i 1850, vendte ganske vist tilbage. Men det slog dog ikke til. En gammel bestemmelse fra 1773, at embedsmænd kun kunne ansættes i Slesvig, hvis de har studeret to år ved Kiels universitet ("bienniet «), havde den danske regering ophævet 1851 for at kunne ansætte dansk uddannede præster $\mathrm{i}$ landsdelen. Bestemmelsen blev genindfort 1864, da man fra preussisk side netop var interesseret $i$ at holde danskuddannede præster ude. Men man måtte atter ophæve den for at kunne skaffe præster udefra. Det fremgår af biskoppens visitatsindberetninger, at præster fra Sydtyskland undertiden ikke ret passede ind $i$ de slesvigske forhold.

De nationale problemer i det nordlige Slesvig voldte både præster og biskop vanskeligheder. Det talte slesvig-holstenske gejstlige nødigt for højt om. På en kirkekonference i Flensborg i juli 1865 
Jorgen Michaclsen

(f. 1830 i Sommersted, d. 1900) var lareruddannet fra Jelling seminarium, teologisk uddannet $i$ Kobenhavn. Han aflagde 1864 ed til den preussiske konge for fortsat at kunne virke blandt sine landsmand $i$ Slesvig.

Han drev ingen national propaganda, men ovede som vakkkelsespradilant stor indflydelse, dels blandt de mange, ikke mindst fra Abenrả, der kom til hans gudstjeneste, dels gennem det vakkelsesarbejde, der blev drevet af kredsen om bladet "Elias“.

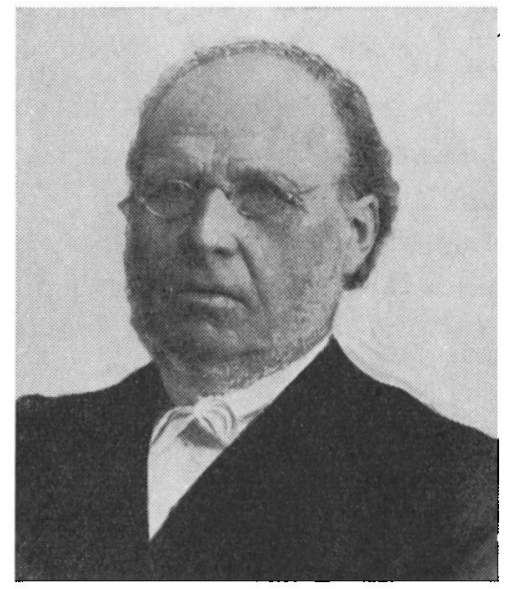

drøftede man tidens fremmedgørelse fra kirken. ${ }^{5}$ Tilstede var $\mathrm{Ha}-$ rald v. Neergaard. Denne godsejersøn fra Oevelgönne i Holsten, der $i$ København havde forberedt sig til en militxr løbebane, men $i$ treårskrigen kæmpede på slesvig-holstensk side, var i sin kirkelige nidkærhed blevet teolog $\mathrm{i}$ sen alder, og efter $1864 \mathrm{i}$ hurtig rækkefølge blevet præst i Starup, Kliplev og Aller. Han shavde et slesvig-holstensk hjerte", men med sin varme tro betragtede han det politiske som en biting og søgte at se den kristne $i$ hvert menneske og ikke slesvig-holsteneren eller danskeren. Han prøvede nu at føre talen ind på det problem, han havde mødt $\mathrm{i}$ de tre nordslesvigske sogne: de, der af politiske grunde var fremmedgjorte for kirken. Men spørgsmålet blev dysset ned af dirigenten, provst Versmann: de ganske »singulære« forhold, som for tiden herskede i Nordslesvig, kunne ikke komme $\mathrm{i}$ betragtning som sagen vedrørende.

Medens biskop Godt forsigtigt begyndte sine visitatser $\mathrm{i}$ de sydlige provstier, Ejdersted og Hütten, besøgte han $\mathrm{i}$ begyndelsen kun uofficielt sogne $\mathrm{i}$ det nordlige Slesvig. I Tørninglen visiterede han ikke officielt for i $1870 \mathrm{og}$ måtte så endda afbryde visitatsrejsen, fordi krigens udbrud fremkaldte en sådan ophidselse i Nordslesvig, at han i sagens interesse « måtte udskyde visitatsens fortsættelse til det følgende år.

Den nationale opposition mærkedes væsentligt i grundtvigske kredse. De holdt sig ofte borte fra sognets kirke og samledes om til- 
rejsende præster nordfra, der prædikede eller holdt foredrag, hvor det nu lod sig gøre, på Rødding eller Brøns højskole, i Mjolden færgegård eller på en af gårdene $i$ sognet.

Disse kredse betragtedes af biskoppen med den største uvilje. Ikke blot af nationale grunde, fordi de kunne være samlingssteder for "Danomanen «. Men også af kirkelige grunde. Biskop Godt gik i Claus Harms' fodspor. Han mente som Harms, at den bedste jordbund for et sundt kristeligt liv er at finde i sognemenigheden, og at national forskellighed ikke behøver at slå en menighed i stykker, for "vi har dog, danske og tyske, én Herre, én dåb, én tro, forkyndt på to sprog «. Derfor formanede biskoppen sine præster til at undga politisk væen og prøve på ved deres virksomhed at knytte menighedernes medlemmer til deres præst og deres kirke, så de ikke skulle behøve at søge deres opbyggelse andetsteds.

Men heroverfor stod de grundtvigske, der havde deres lærefaders overbevisning, at troen ikke kan leve eller dø eller skifte med sognepræsten, og at derfor enhver frit må kunne lade sig betjene af den præst, han ønsker. De havde tillige lært, at den folkelige sammenhæng er forudsætningen for kristeligt liv, og troen derfor ikke kan trives $i$ et nationalt fremmedartet milieu. Derfor kunne den grundtvigske præst Hans Sveistrup ved et møde i Mjolden færgegård i foraret 1869 kategorisk erklære: De tyske har en anden kristendom end de danske, og tysksindede præster kan umuligt udbrede dansk kristendom og fremme dansk fromhed.

Mellem præster med Neergaards indstilling skulle der være bedre muligheder for et samarbejde hen over nationale skel. Neergaard, der $i$ sin missionsiver kunne vandre 7-8 timer fra hus til hus i sit sogn for at opsøge mennesker - og særlig dem, »die ihm nicht gefallen «, - var selv med $i$ et sådant samarbejde ved møder $i$ kirker eller i fri luft. En anden deltager $i$ dette indre-missions-arbejde var præsten i Skrydstrup, sydslesvigeren H. Chr. Lawaetz (f. 1831). Han mente selv, at han var af tysk nationalitet, men havde kontakter i Danmark, bl. a. med Vilh. Beck. Til kredsen hørte endvidere Jørgen Michaelsen (f. 1830 i Sommersted), der var præst i Bjolderup. Med sit danske sindelag ville han ikke svigte den slesvigske befolkning og aflagde derfor eden til den preussiske konge. Endelig var der præsten i Fole, den afgjort dansksindede A. C. L. GroveRasmussen (f. 1836 i Horsens). 
(f. 1815 i $M$ ail

Hans Sveistrup

var $i$ sine unge ar blevet betaget af Vilhelm Birkedals grundtvigske forkyndelse. Han var fra 1861 prast $i$ Rødding, men blev afskediget 1867, da han ikke ville aflagge ed til kongen af Preussen. Han blev boende $i$ Rodding, hvor han prodikede på højskolen eller rejste på foredragsrejser 1870 blev han prast $i$ Vejen.

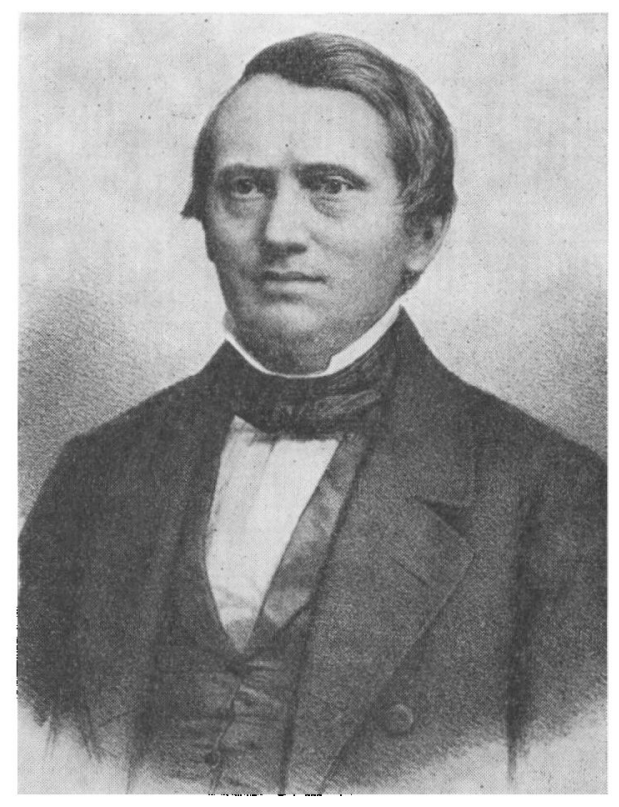

Neergaard døde i 1867 og kom derfor ikke til at opleve, at dette arbejde førte til, at der ved et møde $\mathrm{i}$ Vojens $\mathrm{i}$ august $1868 \mathrm{blev}$ dannet en $»$ Kirkelig Forening til Guds Riges Fremme i Nordslesvig ", hvis organ blev et opbyggelsesblad, "Elias«, som Michaelsen havde begyndt at udgive.

Bevægelsen døde dog snart hen. Det viser, hvor vanskeligt det var at holde det nationale element ude, at Grove-Rasmussen blev afskediget i 1870, fordi han ikke kunne få sig selv til i kirkebønnen at bede for tysk sejr under den fransk-tyske krig.

Den slesvig-holstensk-sindede gejstlighed lagde sin glæde over de preussiske våbens sejre åbenlyst for dagen, på særlig demonstrativ måde ved et møde i Slesvig by den 12.-13. juli 1864, et par uger efter de preussiske troppers overgang til Als. Dér genoprettede man Gustav Adolf-foreningen i Slesvig. ${ }^{6}$

Gustav Adolf-foreningen var en tysk forening, oprettet i Leipzig 1842 som en forening af evangeliske (altså både lutherske og refor-

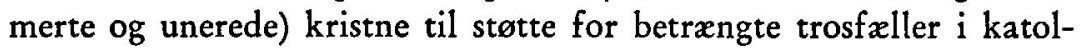
ske lande. Det kunne lyde upolitisk. Men foreningen fik dog let et 


\section{CEliat.}

\section{Jioteng fif guos Jiges fremme.}

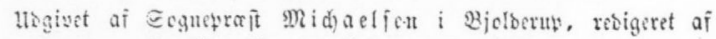

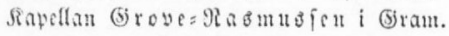

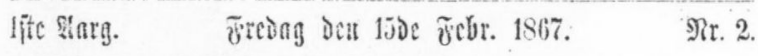

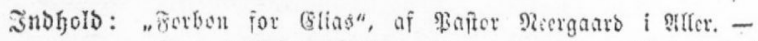

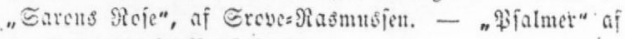
cand. theol. S. \$. Edymit.

$$
\text { forban for ,Eling". }
$$

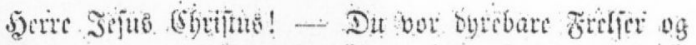
trofalte Getbe! o, for i Raabe til alle bent, ber i Dprigtig:

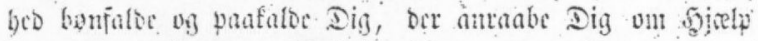

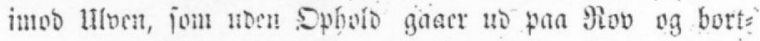

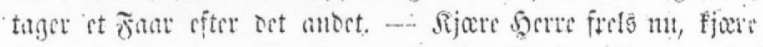

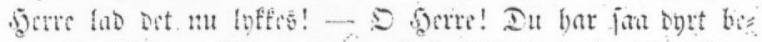
tult fue Butoms Siv, at be bytijabte Ejalc fube blive Dinc

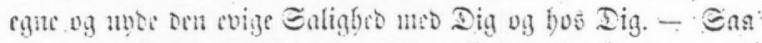

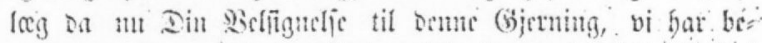

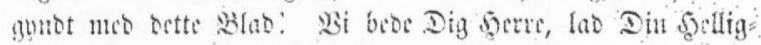

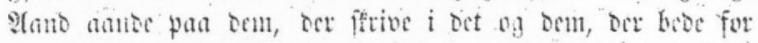
Det! Soere! giv ogjan banet Mri for bet, at bet nian finte

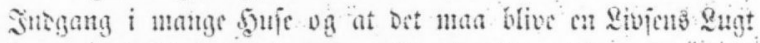
for mange Sjafe, at det ma tjeme bertif, at Der matte ber

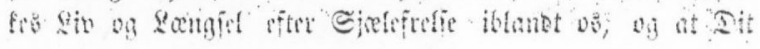

Bladet „Elias“, udgivet fra 1867 af pastor Jorgen Michaelsen $i$ Bjolderup, havde sine lasere $i$ dansktalende pietistiske og hernnhutiske kredse $i$ Nordslesvig. Teksten på den gengivne side er skrevet af den holstenske godsejerson, pastor Harald v. Neergaard $i$ Aller (f. 1826, d. 1867). Da „Kirkelig Forening til Guds Riges Fremme $i$ Nordslesvig" blev oprettet ved et mode $i$ Vojens $i$ august 1868 , blev bladet foreningens organ.

politisk skær over sig i betragtning af den rivaliseren, der var mellem hohenzollernes protestantiske Preussen og habsburgernes katolske Østrig. I hertugdømmerne fik den politisk farve derved, at den blev båret frem af slesvig-holstenske gejstlige, der $\mathrm{i}$ foreningen så et middel til at knytte Slesvig og Holsten nærmere sammen. For- 
eningen var derfor forbudt $i$ Slesvig. Kun i Hütten sogn havde foreningen, som præsten indberetter 1865, ganske $\mathrm{i}$ det stille $\mathrm{i}$ flere år - som den eneste afdeling $i$ hertugdømmet Slesvig - holdt sig "unter dem Druck der Dänenherrschaft « og årlig sendt sit bidrag, ca. 30 mark, til den holstenske hovedforening.

$\mathrm{Nu}$ vedtog den holstenske afdeling ved dette mode at udvide foreningens virksomhed til Slesvig og dermed gøre den til en slesvigholstensk forening. Begivenheden blev fejret med stor festivitas, ikke blot med gudstjeneste og koncert i domkirken, men også med militærmusik $i$ de flagsmykkede gader og med stort festmåltid med et utal af taler. Prædikanten ved gudstjenesten var Bertel Petersen Godt, der i 1850 af den danske regering var blevet afskediget som præst i Felsted, men nu var vendt tilbage fra sit embede som præst i Ruhregnen. Han angreb den danske regerings politik overfor slesvig-holstenske præster i 1850, for dens sprogpolitik i Mellemslesvig og for dens forbud mod Gustav Adolf-foreningen. Han udtalte sin fortrøstning til, at hvad Gud har sammenføjet, kan ikke skilles: Slesvig og Holsten skulle ingensinde skilles. Professor Michael Baumgarten, der i 1849 var gået $\mathrm{i}$ spidsen for gejstlighedens opposition mod Danmark og i 1850 blev afskediget af danskerne fra sit præsteembede ved St. Michaelis kirke i Slesvig, var festens fejrede midtfigur. Han proklamerede det slesvig-holstenske standpunkt som »urevangelisk «, idet Bibelen knytter religion og nationalitet sammen med hellige bånd. Om aftenen gav militærmusikken en "Ständchen * til $x$ re for denne "tapre stridsmand og vakre patriot «.

I tilknytning til dette møde samledes gejstlige fra begge hertugdømmer den 14. juli og vedtog et andragende til det fungerende preussiske styre om at forberede en reorganisation af den slesvigholstenske landskirke. Det var et krav, der allerede havde været rejst i stænderforsamlingen. Det må have virket afsvalende, at civilforvaltningen erklærede det for tvivlsomt, om de pågxldende havde ret til at tale $i$ gejstlighedens navn.

I det hele taget vendte begejstringen sig snart til bekymret uvished.

Den 1. august blev Bertel Petersen Godt konstitueret som generalsuperintendent (d. v. s. biskop, men man ville undgå denne danskklingende titel) for Slesvig stift, definitivt udnævnt 6. september. I anledning af Wien-freden beordrede han en fredsfest $i$ alle stif- 
tets kirker den 4. december (2. sønd. i advent), fordi der var opnået en fred, "der måtte opfylde os med levende glæde «. ${ }^{7}$

Det var hårde vilkår for dansksindede præster at skulle fejre en sådan fest. Men glæden var hos de slesvig-holstenske præster også såre afdæmpet. For dem var hertugen af Augustenborgs sag i ganske særlig grad en hellig sag. Baumgarten og andre toneangivende gejstlige havde overfor prasterne proklameret det som en samvittighedssag overfor Gud at holde fast ved hertugens ret. Men augustenborgeren var ikke indsat $\mathrm{i}$ sine påståede rettigheder.

Der var præster, der fandt sig foranlediget til at måtte minde om dette. "Nu er der plantet et fredens træ, der skal have rod $\mathrm{i}$ retfærdigheden, hvortil også hører, at man ikke tilsidesætter den retmæssige hersker til fordel for en uretmæssig. Man tør håbe på de tyske fyrsters retfærdighedsfølelse, så landets valgsprog opfyldes: »Ret må dog forblive ret«, hedder det $i$ en fredsprædiken ${ }^{8}$ af Simon Gerstenkorn Simonsen, en af de præster, der var blevet afskediget i 1851, men som efter 1864 var præst i Hanved. Han havde 1860-64 været medlem af den holstenske stænderforsamling.

De to år mellem krigene 1864 og 1866 må have været pinagtige nok for de slesvig-holstenske gejstlige, der som provst H. F. Neelsen i Plön følte, at det ville være mangel på gudsfrygt, »hvis vi æreløst og fejt ville bryde troskaben mod den fyrste, der af Guds nåde er vor retmæssige hertug, og som folket også har kåret, og hvis vi af en eller anden grund eller en eller anden til behag ville forråde og sælge vor ret «."

Man aner stemningen hos gejstligheden gennem et replikskifte på den 1. slesvig-holstenske kirkekonference 13. juli 1865. En præst fra Ditmarsken vovede sig frem med en advarsel til sine kaldsf $x$ ller mod at være bekendere af en "Gouvernementskirche« og holde prædikener efter de højeste statsmyndigheders ønske. Provst Versmann afbrød straks videre debat herom med den erklæring, at »Gouvernementsreligion « selvfølgelig ikke er på sin plads nogetsteds i kirken. ${ }^{10}$

Det blev mere og mere klart, at der ingen udsigt var for et selvstændigt Slesvig-Holsten under augustenborgeren. I 1866 faldt afgørelsen, først med Holstens besættelse af preussiske tropper og siden med Preussens anneksion af begge hertugdømmer. Da det blev krævet af de $\mathrm{i}$ forvejen af samvittighedskonflikter hårdt plagede 
gejstlige, at de skulle aflægge ed til den preussiske konge, skrev Chr. Aug. Decker i Leezen: ${ }^{11}$ "Fordærvelige har den sidste tids mangfoldige aflæggelser af embedsed været i Slesvig-Holsten «. Kun een holstensk præst, Chr. Ludw. Schrader i Kiel (tidligere i Bedsted), nægtede eden og fik sin afsked. De øvrige har vel holdt sig til Deckers fortolkning: at undersåtter er automatisk løst fra deres ed, hvis modtageren af eden nedlægger embedet eller på anden måde sættes ude af stand til at udøve det. Yderligere har det været en lettelse, at hertugen fritog befolkningen fra deres ed til ham. I Slesvig kostede tilsvarende edsnægtelser 27 præster deres embeder.

Et brændende spørgsmål blev forholdet til den preussiske unionskirke.

Efter reformationen havde lutherske teologer udformet den lutherske lære i skarp modsætning til Calvins disciple, de reformerte. For den almindelige bevidsthed blev uenigheden om nadverlæren det afgørende.

Denne uenighed har rod i spidsfindige spekulationer over Jesu dobbelte natur, som Gud og menneske. De reformerte benxgter, at Jesu menneskelige natur har del i guddommelige egenskaber. Det endelige kan ikke have del $i$ det uendelige. Derfor er Kristus efter himmelfarten med sin menneskelige natur et bestemt sted $\mathrm{i}$ himlen, og hans legeme og blod er så langt fra brødet og vinen i nadveren, som himlen er fra jorden.

Dette kalder de lutherske for skrækkeligt (»horrendum dictu et auditu «). De hævder lige tværtimod, at Jesu menneskelige natur har fået guddommelige egenskaber - ligesom jernet kan modtage ildens egenskaber og blive glødende. Til hans guddommelige egenskaber hører allestedsnærværelse. Derfor kan han være legemligt tilstede "i, med og under « brødet og vinen, for at bruge Luthers eget udtryk.

Disse modstridende opfattelser gjorde det lange umuligt for lutherske og reformerte at mødes ved nadverbordet, at have "nadverfællesskab «. Men med tiden trådte dogmerne i baggrunden. Pietismen og Zinzendorf lagde mere vægt på et ægte fromhedsliv end på læren. Rationalismen søgte mere eller mindre radikalt at frigøre sig fra de gamle dogmer, der føltes som et kors for tanken. Under den tyske frihedskamp mod Napoleon, der førtes under religiøs begejstring som en kamp for korset mod tricoloren, spurgtes der ikke om del- 
tagernes konfession. Der var på denne baggrund gode muligheder for en tilnærmelse mellem de to trosformer. Tidens førende tyske teolog, Fr. Schleiermacher, erklærede, at der ikke var nogen væsentlig forskel mellem de to konfessioner og støttede tanken om en sammenslutning af de to kirkeafdelinger $i$ en fælles union. Han var den forste, der skrev en dogmatik, der behandler luthersk og reformert troslære under eet.

Preussens daværende konge, Friedrich Wilhelm 3. (1797-1840) var reformert, men Preussens befolkning var overvejende luthersk. Alene af den grund matte han være interesseret $i$ en forening af de to kirkeafdelinger. Men der lå utvivlsomt også en virkelig personlig interesse bag.

Den 27. sept. 1817 udsendte han en kabinetsordre, hvori han proklamerer sin hensigt ved den kommende 300-års jubilæumsfest for reformationen: at gøre begyndelsen til en forening af de to kirkesamfund. Med rette kan han henvise til traditioner i det hohenzollerske dynasti. Adskillige af dets konger havde "med from alvor" lagt sig det på sinde at forene de to protestantiske kirker til én evangelisk kristelig kirke. Han vil selv $i$ unionens ånd fejre reformationsfesten ved at forene den reformerte og den lutherske hofog garnisonsmenighed i Potsdam til én evangelisk kristelig menighed og nyde nadveren sammen med den. Han håber, at dette eksempel vil blive fulgt $i$ de protestantiske menigheder rundt $i$ landet.

Eksemplet blev delvis fulgt. I Berlins kirker og mange steder særlig i de vestlige provinser, hvor der fandtes flest reformerte holdt man, som i garnisonskirken, fælles nadver den 31. oktober 1817. I det hele slog unionen igennem, hvor de to konfessioner fra gammel tid havde levet side om side, foruden i Preussen også i Rhinbayern, Rhinhessen, Baden og Nassau.

I de ikke-preussiske landskirker, hvor unionen ikke var gennemført - Mecklenburg, Holsten, Hannover, Sachsen, Bayern og Württemberg - skabtes der aversion mod unionen. I Holsten angreb Kiel-præsten Claus Harms unionen på det voldsomste: "Fuldbyrd ikke denne akt henover Luthers ben! Så vil han blive levende og da - ve Eder! «12

Han fik næsten ret i sin spådom. Gennem en række personligheder, der af samvittighedsgrunde vendte sig mod unionen, skabtes »en bekendelsestro teologi og et ægte kirkeligt sindelag«. Den tyske 
kirkehistoriker Fr. Nippold (d.1919), der betragtede unionen som frihedskampens skønneste gave til menigheden og tog stærkt afstand fra "den ægte som den uxgte Lutherdoms krav på kirkelig eneberettigelse ", måtte anerkende, at $\mathrm{i}$ det 19. århundrede har den lutherske "bekendelsesdannende kraft « vist sig mere betydningsfuld end unionens kirkeregimente. ${ }^{13}$

Dette er baggrunden for den situation, der opstod, da Hannover, Kurhessen, Nassau, Frankfurt samt Slesvig og Holsten blev indlemmet i Preussen efter krigen med Østrig 1866. Den evangeliske kirke i Preussen blev derved forøget med ca. 4 millioner sjxle fra 5 hidtil selvstændige landskirker. Af disse 5 kirker var den slesvig-holstenske luthersk, i Hannover var kirken overvejende luthersk med betydelige reformerte områder, $\mathrm{i}$ Kurhessen overvejende reformert og unionsvenlig, i Frankfurt luthersk og unionsvenlig og i Nassau uneret. Skulle disse nye kirkesamfund nu indlemmes i unionen?

Unionskirkens styrelse, overkirkerådet, ønskede at vise tilbørligt hensyn til de nye landskirkers ejendommeligheder, men mente dog ikke, at de forskellige kirkeafdelingers særmeninger burde fortrænge »de evangeliske grundsandheder «, som unionskirken byggede på: det rene Guds ord i Bibelen, de tre almindelige trosbekendelser og fremfor alt »der grosse und Hauptartikel « (Luthers udtryk) om synderes retfærdiggørelse for Gud af fri nåde og ikke ved gerninger. På disse grundsandheder skulle præsterne forpligtes. På dette grundlag ønskede overkirkerådet de nye kirkeafdelinger indlemmet i unionskirken. ${ }^{14}$

Men en sådan union ønskede man ikke $\mathrm{i}$ kredsen om "Protestantenverein «. Denne forening var stiftet i 1863 som et teologisk sidestykke til den tyske "Nationalverein «, hvis mål var at skabe et stærkt Tyskland ved at støtte de tyske enhedsbestræbelser med et liberalistisk Preussen som samlingspunkt. Efter det protestantiske Preussens sejr over det katolske Østrig ser »Protestantenverein « det som Preussens opgave at være et værn mod katolicismen. De fremholder en spådom af en spansk katolsk forfatter, Donoso Cortés (d. 1853), at de konfessionelle kampe ville finde deres afgørelse "auf dem Sande der Mark Brandenburg «. Det er reformationen, der har gjort det tyske folk til det første europæiske kulturfolk. Derfor gælder det om ikke at ødelægge det unionsværk, som har gjort den preussiske protestantisme og den preussiske stat store og gjort Preus- 
sen til beskytter af tolerancen i Europa. Med kravet om tolerance forbinder de kravet om radikal frigørelse fra bekendelsesskrifterne. "Den protestantiske kirkes dogmatiske periode er forbi «. Derfor afviser de overkirkerådets $\mathrm{krav}$ om, at presterne skal vare forpligtet på nogensomhelst bekendelse. ${ }^{15}$

Fra modsat hold, i konservative lutherske kredse, ville man ikke lade sig nøje med at bygge kirken på de »fælles evangeliske trossandheder «. Man ville ikke opgive de specielle trossætninger, hvorved den lutherske kirke markerede sin forskel fra den reformerte. Den indflydelsesrige teologiske professor i Berlin, E. W. Hengstenberg, ønskede unionen opløst. ${ }^{16}$ Vil man hindre den lutherske kirke i fuld udfoldelse af sit væsen, vil man skade folket i dets sjæl. Af den lutherske kirkes sønner bestod Frederik 2.'s hær, »måske den gudfrygtigste, som nogensinde har eksisteret «. Derfor advarer han mod unionen som "et i luften svævende, karakterløst fællesskab“, der er en hindring for Preussen $i$ at opfylde sin mission. Det gxlder her en kamp, der ikke er mindre vigtig og betydningsfuld end kampen ved Königgrätz. Det er Hengstenbergs tanke, at der skal organiseres tre områder: det lutherske, det reformerte og det unerede, med hvert sit kirkestyre. Der må ikke ved lov påbydes nadverfællesskab. "Troens højeste mysterium skal ikke gøres til et værktøj for en snedigt smilende kirkelig politik «.

Overkirkerådet advarede mod de to yderstandpunkter, mod „Protestantenverein «, fordi den ville prisgive det evangeliske grundlag og lade en næsten ubegrænset individuel vilkårlighed herske, mod Hengstenberg, fordi følgen af hans plan ville blive, at de tre kirkeafdelinger ville skille sig ud fra den hidtidige preussiske landskirke og indgå nye forbindelser med andre lande. ${ }^{17}$

Kong Wilhelm 1 . havde en konservativ indstilling i kirkelige spørgsmål. Med sin militære opdragelse ville han, som hans afdøde broder, Friedrich Wilhelm 4. sagde, regere kirken som en feltmarskal og betragtede præsteeden som et sidestykke til soldaternes faneed. Selv erklærede han, at han stod på den gamle tro: Jesus er Guds søn og led offerdøden for vor skyld til forsoning for vore synder. Dette trosgrundlag var ham nok. Det måtte de forskellige trossamfund kunne enes om. Teologiske særmeninger burde ikke splitte den union, hans fader havde skabt, og som han derfor nærede den største pietet overfor og ønskede indført $i$ de nye provinser. 
Men han havde Bismarck ved sin side. Bismarck havde sit eget ejendommelige forhold til troens verden. ${ }^{18}$ Han havde $i$ sin tid $i$ den kreds, hvor han traf sin forlovede, modtaget et stærkt indtryk af pietistisk fromhed, præget af en tro og fortrøstning, som han i sin dybe pessimisme havde følt det som en befrielse at blive delagtiggjort i. Det havde givet hans liv et varigt religiost indhold, vel rigtigst således forstået, ikke at han stillede sin personlighed i sin tros tjeneste, men at hans tro tjente hans personlighed (Fr. Meinecke). Han kunne dog ikke forlige sig med pietismens tilbøjelighed til at vikle troen ind $i$ wafsluttethedens bomuld «. Når han daglig $i$ den herrnhutiske løsensbog læste ord af skriften, som var det Guds tale direkte til ham, anvendte han disse ord ikke blot på sit personlige liv, men også på sin politiske opgave. Han følte sig som ved et kald bundet til denne opgave, som han ville opgive, hvis han ikke troede på en guddommelig orden, der havde bestemt den tyske nation til noget godt og stort. Han vidste vel, at politikeren ikke kan »kigge forsynet $i$ kortene « for at foregribe den historiske udvikling efter egen beregning. "Af sig selv kan han ikke skabe noget. Han kan kun vente, til han hører Guds trin lyde gennem begivenhederne og så springe frem og gribe sømmen af hans klædning «. Han vidste også, at man i politik ikke kan følge evangeliets forskrifter. En politik, ledet af hengivende kærlighed, ville være grusomt uansvarlig over for de svage, der trænger til beskyttelse. I politik må afgørelsen træffes udfra politiske motiver, og man må vælge det mindste af to onder. Med barsk realisme erkendte han den etiske problematik i såvel det politiske som i den enkeltes liv. Det gjorde ham ondt, at han med sin politik gav troende kristne forargelse, men han var vis på, at det ikke kunne undgås $\mathrm{i}$ hans kald. "Den, som beskylder mig for at være en samvittighedsløs politiker, skulle først engang selv prøve sin egen samvittighed på denne kampplads ... Gud give, at jeg, udover hvad der er verden bekendt, ikke havde andre synder på min samvittighed, som jeg kun håber på tilgivelse for i tillid til Kristi blod «.

Med denne indstilling traf han afgørelser $i$ unionssagen udfra politiske hensyn. Han indså, at man kun ville styrke uviljen mod Preussen $\mathrm{i}$ de erobrede provinser, hvis man påtvang dem unionen. Han skal have ladet sig overtale til at opfatte den lutherske bekendelse som et godt politisk bånd mellem de gamle og de nye pro- 
vinser og have ment, at unionen vel kunne ofres for en sådan politisk fordel. ${ }^{19}$

Og derved blev det. I oktober 1867 blev det officielt meddelt, ${ }^{20}$ at kongen havde udtalt den grundsætning for de nye landsdele, at en tilslutning til den $\mathrm{i}$ Preussen bestående union ikke er tilstedelig uden ved fri beslutning af de berettigede organer. Således undgik Bismarck at krænke kongen ved en opløsning af unionen og at krænke de erobrede provinser ved at påtvinge dem unionen. Men de, der havde drømt om unionens indførelse $\mathrm{i}$ disse provinser, var skuffede. $\gg I$ stedet for én landskirke fik Preussen seks, den ene mindre end den anden «. ${ }^{21}$ Den protestantiske kirke var ikke blevet styrket $\mathrm{i}$ den store kamp "auf dem Sande der Mark Brandenburg «. "I det ojeblik, da Preussen som tysk stat mægtigere end nogensinde slutter sig sammen og opfylder længe nærede forhåbninger, skal det kirkeligt, mere afmægtigt end nogensinde, falde fra hinanden, skal det, der er dets magts og dets storheds væsentligste bånd, jammerligt skæres over «. Således skrev i 1867 professor David Schenkel, en af medstifterne af $»$ Protestantenverein ${ }^{22}$

Det var et broget væv af interesser, der kom til udtryk i striden om unionen: unionsvennernes rummelighed, de bekendelsestro lutheraneres nidkærhed, "Protestantenverein «s radikale frihedskrav, drømmen om det protestantiske Preussen som værn mod katolicismen, pietet overfor det hohenzollernske unionsværk og endelig som den afgørende faktor: Bismarcks realpolitik.

Nogen endelig afgørelse var dog ikke truffet. Afgørelsen var lagt ud til de enkelte landskirker, der efterhånden fik deres forfatninger, hvorigennem de skulle tage endelig stilling til unionen.

Hertugdømmernes kirke var ufrivilligt kastet ud i denne strid. Den stod forsåvidt ikke uforberedt, som Claus Harms, der stort set blev betragtet som hertugdømmernes kirkelige lxrefader, klart havde udtalt sig mod unionen.

Men spørgsmålet havde dog ikke direkte berørt hertugdømmerne på Harms' tid, da begge hertugdømmer hørte til det danske monarki. Men nu var spørgsmålet bragt hertugdømmerne lige ind på livet med indlemmelsen i Preussen. Man måtte regne med, at der kunne komme reformerte indvandrere til de lutherske hertugdømmer, eller omvendt at lutherske udvandrede til reformerte eller unerede egne. Skulle disse mennesker da være udelukket fra nadverfællesskab med 
deres nye omgivelser? Hvorledes skulle man forholde sig overfor de blandede ægteskaber, der kunne opstå mellem tilflyttere og bofaste? Et andet problem: Kunne det indkaldte mandskab fra hertugdømmerne lade sig betjene af de preussiske garnisonskirker, der var unerede? Man måtte også betænke, at nogle af de tilbagevendte præster $\mathrm{i}$ deres udlændighed havde betjent unerede menigheder $\mathrm{i}$ Tyskland, hvilket var forløbet uden gnidninger.

Der var da også gennemgående stemning for en vis vilje til at lempe sig og $\mathrm{i}$ påkommende tilfælde gå med til nadverfællesskab, hvis altergasten ikke demonstrativt proklamerede en afvigende opfattelse af nadveren.

Men principielt ville flertallet af hertugdømmernes geistlige ikke vide af unionen. Holstens biskop, W. H. Koopmann, der ved sit nære forhold til Claus Harms var blevet bestyrket $\mathrm{i}$ sin winderlige trosoverbevisning om den lutherske bekendelses sandhed «, så - som Hengstenberg - helst unionen opløst. Slesvigs biskop, Godt, var også stærkt påvirket af Harms, men han følte sig i nogen grad i taknemmelighedsgxld til den unerede kirke, idet han var en af de præster, som man mellem 1850 og 1864 havde ladet betjene en uneret menighed i Ruhregnen. På den anden side kendte han befolkningens modvilje mod unionen og frarådede derfor dens indførelse $\mathrm{i}$ hertugdømmerne.

De to biskopper arbejdede i fxllesskab for at hindre indlemmelse i unionskirken. De henvendte sig direkte til kong Wilhelm, der ved en audiens den 18. marts 1867 lovede dem, at kirken i Slesvig-Holsten - som andre steder - kunne være forvisset om kongelig beskyttelse for sin fædrene tro. ${ }^{23}$

Spørgsmålet om unionen blev ivrigt drøftet på konferencer og $\mathrm{i}$ blade. På en slesvig-holstensk kirkekonference i Neustadt (nord for Lübeck) 25. juli 1867 advarede Godt indtrængende mod det mindste skær af tilnærmelse til unionskirken. ${ }^{24}$ Han vidste fra en uofficiel visitats, at i Nordslesvig forlød det $\mathrm{i}$ befolkningen, at de nye præster ikke blot skulle prædike på tysk, men også skulle prædike en ny kættersk lære. "Der er allerede taget så meget fra slesvigerne, det ene efter det andet er revet fra dem. Jeg beder om, at der til alle de øvrige kampe ikke også bliver føjet kampen om troen«.

Begge biskopper deltog $i$ et par store fællestyske konferencer.

Den ene konference, "den tyske evangeliske kirkedag«, var hen- 


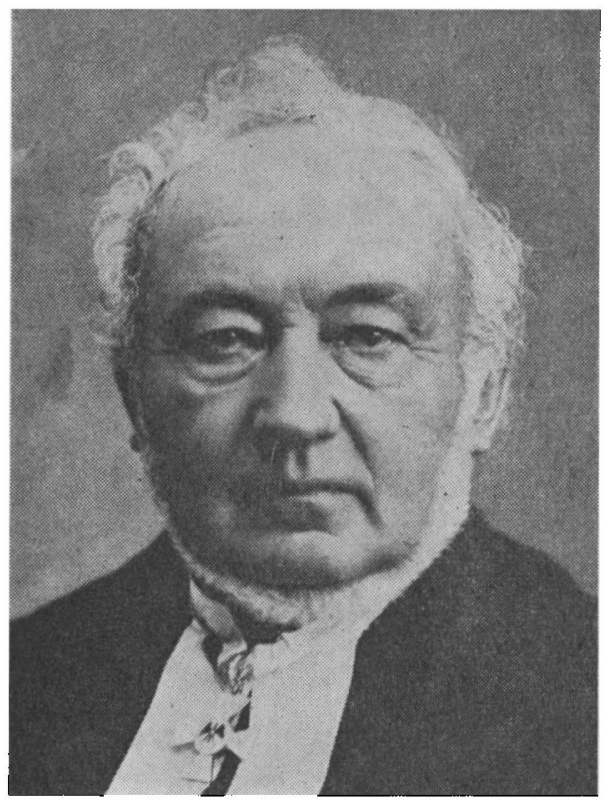

Bertel Petersen Godt

(f. 1814 i Rinkences, d. 1885)

var landmandsson, studerede $i$ Kiel. Under treårskrigen deltog han

- mere moderat end flertallet af

de slesvigske gejstlige -

$i$ protestbevagelsen mod den danske regering,

men blev dog afskediget 1850 .

Han blev da prast $i$ Ruhr-egnen indtil 1864, hvorefter han blev biskop for Slesvig stift.

Som flittig og respekteret visitator ovede han stor indflydelse på kirkelivet.

lagt til Kiel i september 1867. De såkaldte kirkedage havde deres oprindelse $\mathrm{i}$ året 1848, da håbet om Tysklands enhed bredte sig, men samtidig radikale kredse under revolutionen krævede adskillelse af stat og kirke. Man frygtede, hvad der ville ske, hvis kirken stod uforberedt på at skulle ordne sine egne anliggender. Man ville derfor prøve at få dannet et kirkeforbund af lutherske, reformerte, unerede og herrnhuter. Dette lykkedes ikke, men konferencerne fortsatte dog regelmæssigt indtil 1872. Kirkedagens sammensætning - den kaldes blot evangelisk - gav den et unionsvenligt præg. De to biskopper fra hertugdømmerne nægtede derfor at være med i den lokalkomité, der stod for arrangementet i Kiel, fordi "stemningen i vort land ikke er homogen med kirkedagens«. Men de benyttede lejligheden til for dette større forum at tale unionen imod. Koopmann advarede mod »at slynge unionens brandfakkel ind $\mathrm{i}$ vort fredelige land og nøde kirkens tjenere til at gå fra embede og brød «. $\mathrm{Da}$ der også fra anden side faldt hårde ord mod unionen og de reformerte, skønt der var folk af begge retninger til stede, erklærede Godt mere afdxmpet, at ethvert skridt $i$ retning af unionen ville, 
»navnlig for Nordslesvig «, bringe stor nød, men var det nødvendigt, fik det ogsá i Guds navn ske. Men han udtalte sin tillid til, at enhver magtanvendelse lå kongen og hans tjenere fjernt. ${ }^{25}$

Den anden konference, »Allgemeine lutherische Conferenz* (juli 1868), var en nydannelse, direkte foranlediget af de nye provinsers indlemmelse i Preussen. Derfor blev den karakteristisk nok holdt i Hannover med deltagere - gejstlige og lægfolk - fra det nye Preussen, men også fra ikke-preussiske tyske stater. Formålet var en nærmere forståelse mellem de hidtil adskilte lutheranere $i$ det nye Preussen og en forening af alle lutheranere i Tyskland, derfor blev konferencen udtrykkelig kaldt luthersk. Biskop Koopmann var medindbyder og biskop Godt og to provster fra henholdsvis Slesvig og Holsten blandt dem, der stod bag indbydelsen. Af de i alt ca. 1200 deltagere var der godt 20 fra hertugdømmerne. Her stillede førende gejstlige fra hertugdømmerne sig på linie med de mest fremtrædende konservative teologer fra universiteterne i Erlangen (Bayern), Leipzig (Sachsen) og - som det mest konservative - Rostock (Mecklenborg). Modets dogmatiske karakter blev markeret ved et tre timers foredrag af en Erlangen-professor, C. A. G. Zezschwitz. Han påviste, at læren om retfærdiggørelse af tro, kernepunktet $i$ den lutherske lære, nødvendigvis forudsætter den lutherske dogmatiks lære om forholdet mellem Jesu guddommelige og menneskelige natur. Det var som talt ud af Koopmanns hjerte. Mødets modsætning til unionen blev markeret ved en næsten enstemmig vedtagelse af nogle teser, som blev fremsat af Mecklenborgs håndfast konservative biskop Theod. Kliefoth. Der hedder det, at den lutherske kirkes enhed hviler på overensstemmelse i lære og forvaltning af sakramenterne, som fremstillet $\mathrm{i}$ den lutherske kirkes bekendelser. Det er hverken fælles landområde eller fælles nationalitet, der er kirkens grundlag. ${ }^{26}$ Det er Hengstenbergs standpunkt, det er rettet mod ordet "nationalkirke". Det kan synes som en direkte afvisning af overkirkerådets advarsel mod at ville skille sig ud fra den hidtidige preussiske landskirke og indgå nye forbindelser med andre lande. Selve konferencen er $i$ sin sammensxtning og $i$ sit navn en protest mod denne advarsel.

Tilsyneladende er unionsspørgsmålet et kirkeligt problem, men politiske motiver har tydeligt nok, mere eller mindre bevidst, spillet ind og påvirket parternes stillingtagen. Det kom i den følgende-tid 
til en skarp polemik $i$ hertugdømmernes "Kirchen- und Schulblatt" om unionen. Bladets redaktør, pastor Th. Jess i Kiel, var unionstilhænger. Men han advarer mod at blande politik ind $\mathrm{i}$ sagen. ${ }^{27}$ Han advarer unionstilhængerne mod at benytte den politiske forening med Preussen som argument for en kirkelig forening. Han advarer unionsmodstanderne mod af misfornøjelse med de politiske begivenheder at miste evnen til at se på kirkens behov. Han henviser således til, at biskop Godt havde advaret mod unionen ved at henvise til politiske tilstande $\mathrm{i}$ det nordlige Slesvig. Hans meningsfalle, professor Chr. N. Th. Thomsen i Kiel, henviser formanende til sammenblandingen af politiske og kirkelige antipatier, der særligt mærkedes i Hannover. ${ }^{28}$

Men Koopmann erklærer på sin bidske måde, at han er tilfreds med, at Jess forsmår »den ligeså gængse som perfide taktik " at ville bryde modstanden mod unionen ved politisk mistænkeliggørelse af modstanderne, selv om Jess kunne have sparet sig sin »overflødige" advarsel mod at lade politisk misfornøjelse svække evnen til at se uhildet på kirkens behov. ${ }^{29}$

Det var imidlertid ganske umuligt at skjule de politiske tanker. Præsten i Leezen i Holsten, Chr. Aug. Decker, beklagede - ganske på linie med konferencen i Hannover - at nogle drømmer om nationalkirken, og at »territorialismens og nationalismens lænker endnu rasler «. Han opfordrer til kamp for, at ethvert særstandpunkt vinder fri ret til at udforme sig uhæmmet. ${ }^{30}$ Endnu stærkere udtrykker sig en indsender (mrk. W. R.): Det er jo alle steder velbekendt, hvorledes unionsorganer, f. eks. "Neue evangelische Kirchenzeitung " (talerør for det såkaldte "Hofprediger-Partei «), retter begxrlige blikke mod de annekterede lande, ganske som Filip af Makedonien mod de græske stater. ${ }^{31}$ Man kan i diskussionen møde et så stærkt ord som »Annexionslüsternheit« (Chr. L. Schrader).

Imidlertid kunne de samme unionsvenner, der så stærkt advarede mod at blande politik ind i sagen, ikke holde politikken ude af billedet. Jess advarer mod en kirkelig annektering, nemlig en indlemmelse af den lauenborgske kirke $i$ den slesvig-holstenske landskirke. $^{32}$ Det ville nemlig styrke det bekendelsestro parti i hertugdømmerne, da "konkordieformlen « (den strengeste udformning af den lutherske lære fra slutningen af det 16. århundrede) var retsgyldig i Lauenborg (siden 1585), hvad den fra 1764 ikke var $i$ her- 
Friedrich Mommsen (f. 1818, d. 1892)

var kobmandsson fra Flensborg. Som laerd jurist blev han departementschef for justitsvasenct under den provisoriske regering 1848. 1868 blev han prosident for konsistoriet $i$ Kiel, der havde ledelsen af den slesvigholstenske landskirke.

Han var teologisk kyndig, specielt indenfor salmeforskningen. I hans embedstid fik landskirken en forfatning (1876), der gav lagfolket oget indflydelse.

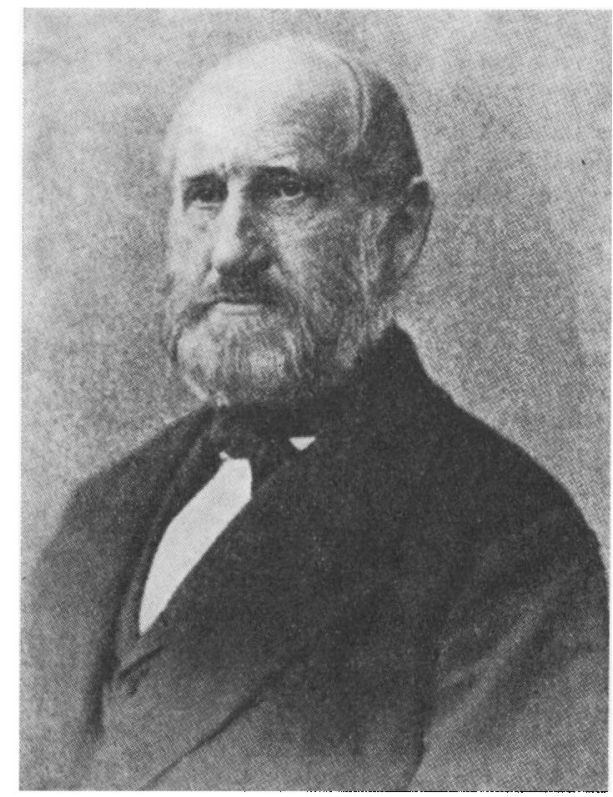

tugdømmerne. Og Thomsen udtrykker direkte sin forargelse over, at Koopmann kan ønske, at det hohenzollernske kongehus skal bortkaste unionen af de evangeliske kirker, der er vidnesbyrdet om dets ret til førerskabet $\mathrm{i}$ det evangeliske Tyskland. ${ }^{33}$

Der er ikke blot politik $\mathrm{i}$ denne bemærkning. Der er også personlig brod i den. Koopmann var i 1864 blevet mistænkeliggjort som "landesfeindlich " $\mathrm{i}$ sin optræden. Medens den ortodokse biskop Godt skånsomt havde talt nordslesvigernes sag, talte Thomsen lidet skånsomt hohenzollernes sag.

Modstanden mod unionen havde dybe rødder $\mathrm{i}$ den slesvig-holstenske landskirke. Motivet kan have politisk farve i den øjeblikkelige situation, men den religiøse faktor synes dog at stikke dybere. Unionen blev ikke indført.

Endnu gennem hele brevvekslingen mellem biskop Godts efterfølger, Theodor Kaftan (Slesvigs biskop 1886-1917) og dennes broder, professor Julius Kaftan i Berlin, der var medlem af overkirkerådet og kaldte sig selv "unionsfanatiker «, mærkes spændingen mellem det slesvig-holstenske lutherske kirkevæsen og den preussiske 
union (Walter Göbell). Biskop Kaftan har intet tilovers for »die ganze Unionsmacherei « og kalder unionen for »konfusion«. Han hævder, at fremad »kommer vi overhovedet kun på konfessionens klare grundlag". Et kirkesamfund skal ikke være et forvaltningsfællesskab, men et tros- og bekendelsessamfund. ${ }^{34}$ Det kunne være sagt på konferencen i Hannover 1868.

Det måtte trække ud, inden landskirken kunne tage endelig stilling til unionskirken. Den måtte først have et organ, der kunne være dens talerør. Dertil krævedes en forfatning for kirken. Som en begyndelse hertil oprettedes der i maj 1868 et konsistorium i Kiel med kultusministeriet (ikke overkirkerådet!) i Berlin som cverordnet instans. Dette konsistorium skulle så bl. a. forberede opbygningen af en forfatning. Konsistoriet fik som medlemmer to jurister, præsidenten, dr. Fr. Mommsen (f. 1818 i Flensborg) og H. F. Chalybäus, der senere blev prxsident efter Mommsen. De øvrige fem medlemmer var gejstlige, nemlig de to biskopper (fra 1876 også biskop A. R. Brömel for Lauenborg) og tre konsistorialråder, provst E. F. Versmann i Itzehoe, klosterprovsten i Preetz, H. Rendtorff, og pastor A. D. Jensen $\mathrm{i}$ Kiel, senere Koopmanns efterfølger som biskop $i$ Holsten.

Konsistoriet udsendte straks en henvendelse til menigheder og præster. Den begynder med den erklæring: Vi holder fast ved vore fædres gamle tro som en dyrebar arv «. De anser den uændrede augsburgske bekendelse for dyrebar. Men på den anden side betoner de, at troskaben mod bekendelsen ikke udelukker et broderligt forhold til de andre evangeliske kirker, og at den slesvig-holstenske kirke da også beredvilligt har givet reformerte en håndsrækning på steder, hvor der ikke var nogen reformert menighed. ${ }^{\mathbf{3 5}}$

Det var en erklæring, der på en gang betonede bekendelsestroskaben og samtidig en mild hjalpsomhed overfor de reformerte, som stemte godt med den overvejende stemning i kirken.

$\mathrm{Da}$ den endelige afgørelse m. h. t. unionen trak ud, gjorde unionens tilhæengere $i$ hertugdømmet sig de bedste anstrengelser for at tale unionens sag. Det førte over $i$ en polemik om stillingen til nyere teologi og specielt til "Protestantenverein «.

Der var $\mathrm{i}$ Tyskland meget røre om yderliggående radikale teologiske skrifter. I 1835 udsendte den 27-årige universitetslxrer i Tü- 
bingen, David Fr. Strauss, sin $»$ Leben Jesu , der for lange tider skulle sætte sindene i den største bevægelse. Man hæftede sig fremfor alt ved Strauss' påstand, at beretningerne om Jesus i det nye testamente er myter, der historisk set er værdiløse, men hvis betydning ligger $\mathrm{i}$ deres idéindhold. $1841 \mathrm{kom}$ Ludw. Feuerbachs „Das Wesen des Christenthums «, der simpelthen vender op og ned på det bibelske ord, at Gud skabte mennesket i sit billede, og hævder, at det er mennesket, der skaber Gud i sit billede. 1863 kom franskmanden Ernest Renans berømte bog om Jesu liv. Den er bygget op på den forudsætning, at evangelisterne, der har overleveret os billedet af Jesus, står så langt under ham, at de har forvansket billedet af ham. Derfor er deres beretninger legender, som holder os fast $i$ en overmenneskelig verden. Men man øjner bag hver linie i beskrivelsen »den guddommelige skønhed «, som er blevet falsk gengivet af dem, der ikke forstod ham. 1864 udgav David Schenkel et »karakterbillede " af Jesus. Han vender sig skarpt mod dem, der vil gøre Kristus til et »dogmatisk begreb « og vil i stedet tegne et billede af Jesu »livsvarme, åndsfriske personlighed «, idet han fjerner alle overmenneskelige træk og søger at følge Jesu udvikling, som man følger enhver anden historisk personligheds udvikling. Schenkel spillede en stor rolle $\mathrm{i}$ "Protestantenverein «, hvor man så det som opgaven at slå bro over kløften mellem kirken og tidens kultur, bl. a. ved at give den "frie forskning « ret til at prøve kirkelæren på videnskabens resultater. "Den protestantiske kirkes dogmatiske periode er forbi «, skrev Schenkel.

Man anede al denne tidens teologiske radikalisme bag en artikel, som redaktøren af "Kirchen- und Schulblatt«, Th. Jess i Kiel, i 1869 skrev $\mathrm{i}$ bladet. Han skitserede et forslag til en enhedskirke, hvor præsteløftet skulle erstattes med den bekendelse: "Jeg tror, at Jesus Kristus er min Herre

Dette gav anledning til en voldsom polemik, hvor hovedmodstanderne var den teologiske professor R. A. Lipsius i Kiel og biskop Koopmann. Det blev reelt en strid om, hvorvidt bekendelsesskrifterne skulle være forpligtende for præsterne. Lipsius og hans fløj hævdede, som Schleiermacher, at den religiøse erfaring er hovedsagen. Mennesker udtrykker deres religiøse erfaringer på forskellig måde. Bekendelsesskrifterne er kun sådanne menneskelige og mangelfulde forsøg på at udtrykke den kristelige erfaring. De er ikke 
nødvendige til frelse ("heilsnothwendig"), og de bør derfor ikke være forpligtende for presterne, men hele den kristne lxrebygning bør kunne underkastes »den frie forskning «.

Heroverfor gik Koopmann i sin trosiver til angreb, idet han som en modstander skriver - fortrestningsfuld og stormende ivrig fremsætter sine påstande med anskuelig livlighed og burlesk populær humor, der of te svarer lidet til sagens værdighed. Han finder netop Bibelens og bekendelsesskrifternes lærepunkter wheilsnothwendig ", idet det drejer sig om sandheder, der hænger sammen som leddene $\mathrm{i}$ en kæde. Fjerner man blot eet led, styrter det hele sammen. Fjerner man f. eks. læren om forsoningen ved Kristi død, vil mennesket ikke opfatte sin syndselendighed i sin rette dybde, og så bliver retfærdiggørelsen let til, at mennesket retfærdiggør sig selv. Fjerner man treenighedslæren og dermed læren om Guds hellige ånd, vil denne let på blasfemisk måde blive erstattet af tidsånden. Fjerner man troen på Jesu allestedsnærværelse, bortfalder det højdepunkt $\mathrm{i}$ vidnesbyrdet om hans virkelige nærværelse $\mathrm{i}$ nadveren, som ikke findes bedre, mere bibelsk, mere virksomt og mere anskueligt udtrykt end i konkordieformlen. Fjerner man troen på Jesu legemlige opstandelse, berøver man mennesker troen på en personlig levende og nærværende frelser. For et menneske $i$ syndenød eller en døende, for hvem det gælder at overvinde syndens og dødens angst, betyder det intet, at man fortæller om en for 1800 år siden afdød jødisk rabbi, der fuldkomment har virkeliggjort forholdet mellem det endelige og det uendelige. Stiller man præsterne frit overfor bekendelsesskrifterne, og giver man kirkelæren til pris for den frie forskning, gør man kirken til en "Allerweltskirche", hvor det er lige meget, om man forkynder Jesus som et gudmenneske eller som en antik Nathan der Weise. Man åbner da kirken for "der Mythenheros" Strauss og for »Protestantenverein«, der bag sine frasers prægtige gevandt viser "sit ligblege ansigt $«$.

Striden mellem de to parter var ualmindelig skarp. Det var ikke så meget unionsspørgsmålet som spørgsmålet om kirkelæren, der kom til at optage sindene og gribe ind $\mathrm{i}$ kirkelivet.

For at modvirke skadelig indflydelse fra Lipsius og hans liberale fløj, begyndte den unge præst i Ulvesbøl i Ejdersted, senere kendt for sin vidtspændende virksomhed i Breklum, Chr. Jensen (f. 1839 i Faretoft) i 1870 at udgive "Sonntagsblatt für's Haus«. Han ville 


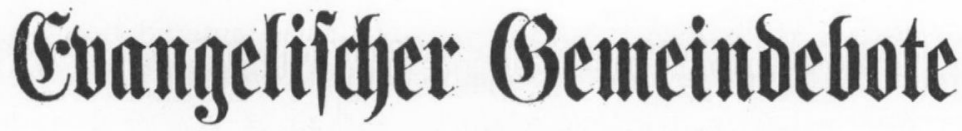

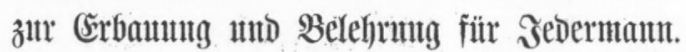

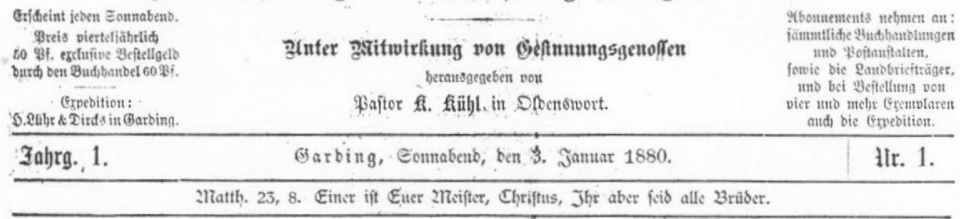

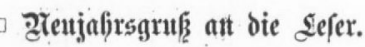

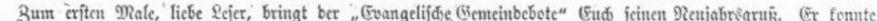

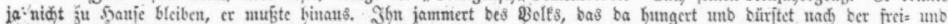

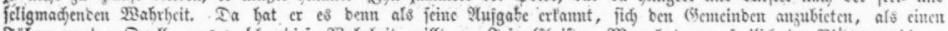

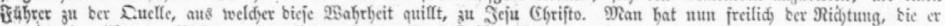

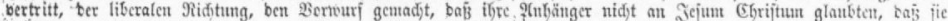

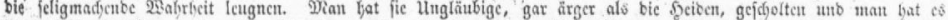

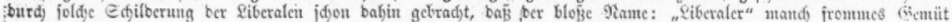

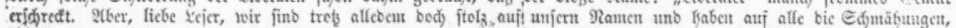

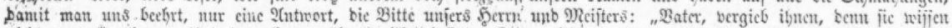

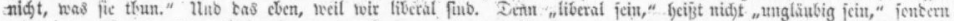

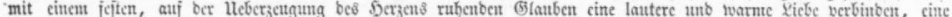

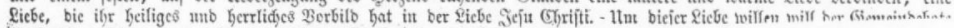

„Evangelischer Gemeindebote“, udgivet fra 1880 af pastor Kühl $i$ Oldensworth (f. 1842 $i$ Krumstedt), er redigeret $i$ den, ,liberale teologi“s ånd. Det står — som den tyske "Protestantenverein" - frit over for kirkens dogmer og straber at forlige kirkens forkyndelse med tidens kultur og videnskab. Bladet fandt fortrinsvis lasere $i$ de frisiske egne.

deri med simple ord fremstille den jævne bibeltro og "male folket Jesu kors for øje «. Bladet blev sendt til soldaterne under den fransktyske krig og vandt stor udbredelse $\mathrm{i}$ hertugdommerne.

Fra modsat side begyndte en præst, Karsten Kühl (f. 1842) i Oldensworth, i 1880 at udgive bladet "Evangelischer Gemeindebote«. Det stod på "Protestantenverein «s rent subjektivistiske standpunkt, hvor man ikke anerkender bibel og bekendelsesskrifter som rettesnor for troen, men kun "hvad vort eget hjerte vidner for os«. Bladet kom en tid som gratis tillxg til "Tondernsche Zeitung og fandt en del udbredelse, særlig $i$ de frisiske egne. Nogle præster vil vide, at det virker skadeligt og synes at være et evangelium for befolkningen.

Men alt $\mathrm{i}$ alt var konservatismen den stærkeste. Gang på gang erklærer præsterne, at deres menigheder bevidst hænger ved fædre- 
nes tro. Ca. 130 præster tiltrådte en erklæring fra en konference $i$ Neumünster i september 1880, der hævder, at »Gemeindebote « strider mod Guds ord og den evangelisk-lutherske kirkes lære, og at det er uforeneligt med præsteembedet $\mathrm{i}$ kirken at udgive et sådant blad. Konsistoriet, der lige fra begyndelsen havde lovet at holde fast ved "vore fædres gamle tro«, bekendtgjorde nu, at Kühls standpunkt ikke var kirkeligt berettiget. En præst i Egernførde blev fradømt sit embede for sine radikale udtalelser $\mathrm{i}$ forbindelse med et forsvar for »Gemeindebote «.

På sine visitatser var biskop Godt på vagt overfor præster med hældning til radikale teologiske standpunkter. Han går ikke af vejen for at fremhæve alvor eller dygtighed hos dem, hvor sådant findes, men han søger gerne at lede en sådan "Protestantenvereinler « ind på et andet spor, og ikke sjældent kan han med tilfredshed notere, at vedkommende præst er blevet mere »positiv «. Der er selvfølgelig også præster, der ikke når udover "liberaliserende floskler «, så biskoppen lidt vemodig noterer, at vedkommende ikke synes at have forandret sig væsentligt. Skarpe sammenstød med sådanne præster har han $\mathrm{i}$ det væsentlige undgået.

Alt $i$ alt vidner visitatsberetningerne om en afvisende holdning overfor »Protestantenverein «. Den bekendelsestro Claus Harms' indflydelse mærkes i præstestanden. Befolkningen har næppe kunnet følge de subtile tankeudviklinger i polemikken om kirkelæren, men som de med slesvigsk konservatisme reagerede mod, at Preussen skulle "annektere " deres kirke, har de også reageret mod, at der skulle påføres dem en ny og »kættersk « lære.

Den hurtigt voksende industrialisme i Tyskland skabte god jordbund for socialismen. Tidens socialistiske agitation voldte gejstligheden bekymringer.

Den socialistiske bevægelse, der ved denne tid sydfra trængte ind $\mathrm{i}$ hertugdømmerne, havde sin tilknytning $\mathrm{i}$ »den almindelige tyske arbejderforening ", som var stiftet 1863 med Ferd. Lassalle som præsident. Lassalles tanke var, at gennem den almindelige valgret skulle der gives arbejderne så megen indflydelse pá lovgivningen, at de kunne gennemtvinge fornøden økonomisk støtte fra staten til oprettelse af egne produktionsforeninger og dermed befri arbejderklassen fra afhængigheden af »den jernhårde lønningslov *. 
Bevægelsen havde altså ikke den marxistiske karakter, de internationale og revolutionære perspektiver, som prægede "Eisenacherne", d.v.s. "det socialdemokratiske arbejderparti«, der var stiftet i Eisenach 1869 med Bebel og Liebknecht som ledere. Men Lassallebevægelsens agitation havde dog en sådan karakter, at den nok kunne være en trussel mod kirkens stilling $i$ befolkningen.

Fra Altona og Hamborg udgik agitationen til egne $i$ hertugdømmerne, hvor misfornøjelsen med de sociale forbold var særlig stor, særlig Ditmarsken og godsdistrikterne mod øst. I det nordlige Slesvig var der kun ringe jordbund for bevxgelsen. Afstanden til bevægelsens kraftcenter var for stor. De sociale forhold var for sunde. Hvad der dér fandtes af opposition, havde national karakter.

Ved rigsdagsvalget 1871 fik partiet vel ingen kandidater valgt, men det fik dog så mange stemmer, at man kaldte Slesvig-Holsten for »hovedrekrutteringsområdet for lassallerne«. Lassalle selv var død 1864 . I 1871 blev Wilh. Hasenclever ${ }^{36}$ præsident for arbejderforeningen. Han og en rakke andre agitatorer, bl. a. Otto Georg Reimer, ${ }^{37}$ drev $i$ den følgende tid en energisk agitation med det resultat, at partiet ved rigsdagsvalget 1874 fik mere end en trediedel af stemmerne $\mathrm{i}$ hertugdømmerne, og Hasenclever og Reimer blev valgt $i$ to holstenske valgkredse. Slesvig-Holsten blev herefter betegnet som »det af den socialdemokratiske springflod mest truede punkt i Tyskland«. Der blev i den følgende tid skredet kraftigt ind mod agitatorerne. Ved valget i 1877 mistede partiet begge mandater. ${ }^{38}$

Med stor bekymring betragtede gejstligheden partiets mbestræbelser for at tilintetgøre alt kristeligt «. Agitatorerne, der drog rundt wsom vandreprædikanter for en ny lære « spillede på det religiøse på en i gejstlighedens øjne forargelig måde. Det blev f. eks. sagt, at der var ingen kristendom hos de forende kredse, og at den kun var at finde hos arbejderne, der udgjorde 95 pct. af folket. Man kaldte Kristus den første socialist. Man krævede valgdagen henlagt til en søndag eller anden helligdag, vendte sig mod det gejstlige skoletilsyn og krævede »folkefrihed mod præsteskabets tryk «.

Man kan imidlertid ikke beskylde de gejstlige for ligegyldighed overfor sociale misforhold. De giver ofte værdifulde oplysninger derom. Sxrlig fra Ejdersted og fra godsdistrikterne foreligger mistrøstige skildringer. 
På grundlag af indberetningerne fra Ejdersted kan man tegne følgende billede af forholdene dér:

Den indbringende handel med fedekveg til England har taget et stort opsving i det sidste par decennier. Den har givet kvægopdrætterne store indtægter, men har også medført, at meget hidtidigt agerland er lagt ind til studegræsning. Der bliver derfor mindre arbejde til daglejerne, men også til håndværkere som hjulmagere, landsbysmede og bødkere. For digearbejdernes vedkommende kommer dertil, at også deres arbejdsmuligheder formindskes, idet man går over til "Steindossirung « af digerne. Adskillelsen mellem rige og fattige gør under disse forhold hurtige fremskridt.

Præsterne kan bruge hårde ord om ejerne af de store græsgange. Der skal blandt dem findes mammontjeneste, gerrighed, spillelidenskab, samt "pynte- og nydelsessyge, der stiler ud over deres stand og dannelse«. De vil ikke kaldes bønder, men »Hofbesitzer«. Adskillige af dem tager bolig $\mathrm{i}$ byerne. I Kotzenbøl er de 5 af $11 \mathrm{Hau}-$ berge ikke beboet af ejerne. I Oldensworth, hvor halvdelen af gårdene er forladt af ejerne, kommer forvaltningen og indflydelsen som følge af den gamle landsforfatning $i$ hænderne på nogle få, "som i snæverhjertethed og misforstået standsbevidsthed altfor of te bruger deres stilling til egen gavn og derved indirekte til beklageligt tryk for småfolk *.

Særlig skal kløften mellem herskab og tyende være stor - større end mellem bønder og arbejdere. Den 12. maj er der en formelig "tjenestefolksvandring ", men også i november, ja selv helt udenfor terminen skiftes tyende. Præsterne giver herskabet meyet af skylden. Man overlader tyendet til sig selv. "Der vil ikke let findes et herskab, i hvis sjal der er ønske om at drage omsorg for tjenestefolkenes sædelige vandel $\ll$, hedder det fra Tetenbel. En anden præst betragter det som roden til al elendigheden, at herskabet betragter tyendet som »arbejdsmaskiner«. I Østerhever skal tyendet være ved at blive wen helt forvildet kaste«. De tager til Garding "for at efterkomme det kødelige begær«. Derfra stammer sognets ulykker. Og da arbejderklassen udgår af tyendeklassen, trues også den med demoralisation.

Vanskeligheden ved at få arbejde skaber arbejdsløshed. Derfor forlader mange unge deres hjemsogn straks efter konfirmationen for at søge deres udkomme andetsteds. Men også mange xldre af både 
middelstand og arbejderstand søger bort. Der noteres $i$ de fleste sogne meget betydelig nedgang $i$ indbyggertal - $i$ Vesterhever en nedgang på ca. 24 pct. fra 1865 til 1879. Mange huse stăr tomme eller rives ned. På den anden side medfører udvandringen en »tjenestefolksnød «, der atter fører til, at skarer af fremmede arbejdere kommer for at tinge om arbejde - gerne søndag formiddag $i$ kirketiden, bemærker en præst bittert. Ganske naturligt bemærker præsterne, at disse tilstande har uheldige følger for kirkelivet. Velstanden hos jordbesidderne fører næsten overalt til hovmod, ligegyldighed, trosfattigdom og vantro. Og for de fattige gxlder, at »bekymringen for det kære brød desværre $i$ for høj grad lader bekymringen for sjælens frelse træde i baggrunden «, som det hedder fra Follervig med de mange digearbejdere. Mange småfolk må bruge søndagen til at passe deres egen bedrift, da de på ugens andre dage må arbejde for andre.

På denne baggrund frygter nogle af præsterne, at socialdemokratiske "Irrthümer « skal finde indgang $\mathrm{i}$ befolkningen.

I godsdistrikterne i Svansen og Dänischwold understreger præsterne, at der er et skarpt skel mellem stænderne. Der hersker nødstilstand hos dem, der hører under godserne. Daglønnen følger ikke de stigende priser på de nødvendigste livsfornødenheder. Daglejeren lever med kone og børn år ud og år ind, dag for dag i den samme afhængighed af befalinger fra godset, og er kun bedre eller ringere stillet, efter som godsherren sørger mere eller mindre godt for ham. Særlig uheldigt er det, hvor - som i Svans sogn - alle syv godser beboes af forpagtere. I lobet af 10 år er befolkningsantallet i Krusendorf sunket fra ca. 1000 til ca. 900 , fordi mange foretrækker at være arbejdere $\mathrm{i}$ Kiel fremfor at høre under et gods. Unge arbejdere, der lever på ugeløn, fører et ubundet vandreliv i utilfredsstillet søgen efter højere løn for derpå at sætte det indtjente over styr $i$ værtshusene. De moralske følger skildres $\mathrm{i}$ grelle farver: de indskrænkede boliger, for det meste med én stue, som lader børn se, hvad de ikke skulle se, børnenes mangelfulde opdragelse, særlig ved mødrenes hyppige fravær, karlenes og pigernes samvær på godserne - alt det og meget andet har en i sandhed sørgelig afstumpethed af den moralske samvittighed til følge, skriver en ung præst $i$ Krusendorf, idet han bringes til at tænke på, at der står om Jesus, "han græd over folket $\ll$. 
Som i Ejdersted noterer prxsterne de uheldige følger for kirkelivet. Den gennemgående råhed på avlsgårdene kvæler kun alt for let enhver religiøs følelse. Inderster og daglejere shar ingen søndag *. De er bundet til at arbejde for godsherren alle ugens seks dage og må bruge søndagen til at passe deres egen bedrift, så at deltagelse $\mathrm{i}$ gudstjenesten wkun kan købes ved forfald af den hjemlige okonomi «.

Socialdemokratisk indflydelse $\mathrm{i}$ disse sogne omtales kun lidt. I Riseby skal den have voldt en del forstyrrelse. I Siseby har præsten set nogle af de skrifter, som kolportørerne har udleveret " $i$ den bekendte brandrøde indbinding .

Gejstligheden står som sagt ikke udeltagende overfor social nød. Den er i tvivl om, hvad der kan gøres. Men den er ikke i tvivl om, at socialismen ber bekæmpes.

På en kirkekonference i Tønning ${ }^{39} 1869$ blev kirkens stilling til ejendomsspørgsmålet drøftet. Provst Franz Volkm. Reinh. Hansen fra Slesvig ${ }^{40}$ indledte diskussionen med et noget abstrakt foredrag med lange kirkehistoriske tilbageblik. Han ser det som problemet, at standsmodsxtningerne, som er en nødvendig følge af kulturudviklingen, har ført til de revolutionære bevægelser, der ligger tilbage i tiden, og til den socialistiske og kommunistiske fare, der ligger foran i tiden. Der mangler forstålse for den sxdelige betydning af standsforskellene: at alle skal se på det fælles vel, de lavere stænder ved husholderisk anvendelse af ejendommen, middelstanden ved ejendommens anvendelse $i$ velgørenhedens tjeneste, de øverste stænder ved udbredelse af samfundssind i de videste kredse. Denne indre udligning af modsætningerne har kirken forsømt at bidrage til, idet den ensidigt beskæftiger sig med spørgsmålet, hvorledes en synder bliver salig. De varste misforhold lader man tålmodigt bestå, medens indførelse af en ny katekismus, salmebog eller gudstjenesteordning sætter sindene $\mathrm{i}$ den største bevægelse. Det sociale spørgsmål har kirken overladt til staten.

Denne udvikling anser provsten for en typisk fortsxttelse af udviklingen $\mathrm{i}$ de romersk-katolske lande, hvor man først og fremmest lægger vægt på at anvende sin ejendom til kirkelige formål, til gaver til kirker, klostre o. s. v. Men han formaner til, at man i de germansk-protestantiske folk følger Schleiermachers profetiske ord, der sætter det som mål for kirken at virke lutrende på alle områder, det borgerlige, statslige og nationale. Staten begynder da også at 
forstå, at den må give kirkens religiøst-sædelige indflydelse større spillerum, for husholderiskhed, velgørenhed og samfundssind udspringer af næstekærlighed, og den kan staten med al sin magt hverken påbyde eller fremkalde. Og kirken begynder at forstå, at den mister sin indflydelse ved kun at tænke på den kirkelige lære og lade den moralske indflydelse $i$ samfundet ude af betragtning. Det må være det tyske folks verdenshistoriske opgave at samle alle kræfter om en moralsk styrkelse af folkets liv. I kampen mod $\mathrm{Na}-$ poleon viste Schleiermacher det tyske folk dets opgave: en sejr for det germanske væesen over det romanske.

Disse teoretiske betragtninger over det tyske folks "verdenshistoriske* opgave, bygget over stænderstatens samfundssyn, giver intet svar på det rent håndgribelige spørgsmål, som præsterne $i$ deres daglige arbejde som medlemmer af sognenes fattigkollegier var stillet overfor, og som ganske jæunt blev rejst under den følgende diskussion af en af Flensborgs bedste præster, H. F. L. A. Birckenstaedt (f. 1833). Han fremholder det urimelige $i$, at skønt kristendommen er bestemt for de fattige, så vender de fattige kirken ryggen. I byerne er det honoratiores, på landet de velhavende bønder, der besøger kirken. Det er påtrængende nødvendigt, at barmhjertig broderkxrlighed søger at afhjælpe nøden. Ellers vil det arme folk hjemfalde til »dem Lassalleanismus «. Dennes repræsentanter har forlængst fremstillet *mavespørgsmålet « som det mest brændende, og de opfordrer de fattige til at slutte sig til dem, fordi de har wnævernes magt $\%$. Det gxlder at møde denne magt med kxrlighedens magt. Men »hvorledes? « spørger Birckenstaedt. Det ønsker han svar på. Konferencen synes dog ikke at have givet ham noget egentligt svar. Derimod var der almindelig enighed om, at socialismen var en fare, som måtte bekæmpes.

Socialismen var langt fra trængt ind $i$ alle sogne. I mange landsogne nævnes »den moderne socialisme" slet ikke, og sker det, er det blot for at slå fast, at der ikke er jordbund for den. Det kan være, fordi der ikke er storre sociale forskelle, eller fordi der her\$ker »patriarkalske forhold «, eller fordi de velstående viser fornøden hjelpsomhed overfor de ringere stillede, eller endelig fordi beboerne er $*$ for besindige og for fornuftige $\ll$.

Men der er også præster, der aner, at selv om socialismen ikke synes at have vundet åbenlyse tilhængere, så ligger dog socialistiske 
anskuelser mere eller mindre bevidst $\mathrm{i}$ luften. Arbejdere og tjenestefolk stiller store fordringer. "Naturligvis er disse krav tildels fuldt berettigede, men den ånd, hvori de bliver stillet, er ikke den kristelige kærligheds og ydmygheds ånd «, skriver en bekymret præst i Ejdersted, (D. Th. J. Peters i Østerhever 1873). "Socialdemokratiets gnist ulmer også her under asken «, hedder det fra Hütten sogn 1879.

Der er da også præster, der bevidst søger at modarbejde socialismen. I Tetenbøl i Ejdersted håber en præst, (Ernst Ed. Evers), at en sygekasse, der nyder støtte fra de besiddende, også vil komme sjalesorgen tilgode, idet »fattigdom nu engang ikke lader sig trøste ved ordet alene«. En præst i Munkbrarup (J. C. F. Johnsen) har ladet sig stille $\mathrm{i}$ spidsen for sognets sygekasse $\mathrm{i}$ håb om derved at modvirke socialdemokraternes agitation og for at give arbejderne et håndgribeligt bevis på, at præsten bekymrer sig om fjerdestands timelige vel. De gejstlige interesserer sig også for oprettelse af sparekasser, for at tjenestefolk og småfolk kan vænne sig til sparsommelighed, så færre behøver at søge fattigunderstøttelse. På Pelvorm har den begavede, noget docerende, men afholdte prast, J. H. C. Bernhard, - med støtte fra regeringen i Slesvig - oprettet et folkebibliotek med skrifter af de bedste kristelige folkelige forfattere $i$ håb om, at befolkningen kan blive oplyst på rigtig måde om de brændende sociale spørgsmål. Det hænder, at præster optræder direkte mod den socialdemokratiske agitation. En præst i Vabs (J. H. Sierck), beretter 1876, at han for tre år tilbage har holdt forsamlinger $\mathrm{i}$ skolerne, $\mathrm{da}$ socialdemokrater $\mathrm{i}$ anledning af rigsdagsvalget "havde strøet deres ukrudt $i$ arbejderfamilierne hus efter hus «. Udfaldet af valghandlingen viste, at det var lykkedes ham wat slå dem fuldstændig af marken!«

De anførte eksempler vidner om, hvorledes præsterne stod med front mod den socialdemokratiske bevægelse. Det fremgár også af det anførte, at adskillige prrester meget vel så det berettigede $\mathrm{i}$ kravet om forbedringer af de sociale forhold, men at de ikke kunne forlige sig med, at fordringerne ikke blev stillet $\mathrm{i}$ »den kristelige kærligheds og ydmygheds ånd «. Endvidere synes det, at stænderstatens samfundssyn levede indenfor gejstligheden. Når dertil kommer de socialdemokratiske hårde angreb på kirken, er det forståeligt, at præsterne stillede sig $i$ forsvarsstilling overfor bevægelsen, og at denne på sin side yderligere skærpede kampen mod kirken. 
Det var ikke blot den preussiske unionskirke, "Protestantenverein « og "Hasenclever og konsorter «, der foruroligede de kirketro i hertugdømmerne. Det store skræmmebillede var tidsånden, »den herskende liberalistiske tidsånd «.

Samtidig med, at dogmet om den pavelige ufejlbarlighed blev proklameret i Vatikanet juli 1870, udbrød den fransk-tyske krig. Det lykkedes Bismarck at få de sydtyske stater med i den fælles nationale krig mod Frankrig. Ved sejren erhvervede Tyskland ElsassLothringen. Ved proklamationen i Versailles af Wilhelm 1. som tysk kejser blev Tysklands enhed en realitet.

Opgaven måtte nu blive at befæeste enheden indadtil. Her mødte Bismarck den stærkeste modstand fra det katolske centrumsparti og dets begavede leder, Windhorst. Efter Østrigs udelukkelse havde $\mathrm{i}$ Tyskland protestanterne et flertal på ca. 26 millioner indbyggere mod ca. 14 millioner katoliker. I den aktuelle situation måtte centrumspartiet ønske at svække det protestantiske Preussens magt ved at søge mest muligt af enkeltstaternes selvstændighed bevaret. Dette måtte bringe dem i modsætningsforhold til Bismarck.

Men dertil kom nu vatikan-konciliets erklæring om pavens ufejlbarlighed i spørgsmål vedrørende tro og sæder, hvilket kunne opfattes som pavens ret til ikke blot at diktere retningslinierne i dogmatiske spørgsmål, men også i politiske spørgsmål. Bismarck måtte derefter betragte den katolske gejstlighed som en politisk institution under kirkelige former. I betragtning af, at katolikker i Tyskland skulle modtage politiske direktiver fra et sted udenfor rigets grænser, talte man om, at man havde fàet en trojansk hest indenfor rigets mure.

Rent konkret lå faren særlig deri, at katolicismen var stærkest representeret $\mathrm{i}$ det anti-preussiske Sydtyskland og i det tyskfjendtlige Elsass-Lothringen og Polen. Bismarck kunne særlig i Polen konstatere fremgang for polsk nationalitet på bekostning af tysk nationalitet. Katolske prester fik befolkningen til at tro, at tysk og protestantisk var lige så identiske begreber som polsk og katolsk. En katolsk prest fra Polen erklærede $i$ landdagen, at en " forbrødring « mellem polakker og tyskere var umulig.

For at svække katolicismens magt gennemførte Bismarck en række love, der ramte den katolske kirke hårdt. Der var en særlig katolsk afdeling i kultusministeriet; den blev ophævet. Tilsynet med sko- 
lerne, der havde påhvilet præsterne, blev inddraget under staten. Ingen katolsk præst kunne få ansættelse, uden at det blev anmeldt for de statslige myndigheder. Der blev fastsat strenge straffe for opsætsige præster. Bøder og fængselsstraffe ramte mange gejstlige. Et utal af katolske gejstlige embeder stod ledige. Ca. 2 millioner katoliker var uden gejstlig betjening.

Bismarck fandt støtte $\mathrm{i}$ denne politik hos de national-liberale. Den ukirkelige liberalisme frydede sig over denne kamp mod katolicismen. Man påstod, at den katolske kirke ikke mere var en kulturmagt og kaldte derfor denne politik »kulturkampen «. Men mange evangelisk troende blev forstemte over denne politik. De følte større fællesskab med de forfulgte katolikker end med »guldløse liberale og jøder «.

Ganske særlig hårdt ramte den såkaldte "Zivilstandsgesetz " (1874), "loven om xgteskabets afkristning « har man kaldt den. Ved den blev der indført tvungen borgerlig vielse, idet registre over fødsel, xgteskab og dødsfald fremtidig skulle føres af de civile myndigheder. $\mathrm{Da}$ loven gjaldt for hele Preussen, kom den også til at gxlde protestantiske områder. Hvor man gennem århundreder havde været vant til, at kirken fulgte et menneskes liv fra vuggen til graven, blev alt dette nu et rent borgerligt anliggende.

Det føltes i kirkelige kredse som et hårdt slag, at de kirkelige handlinger nu var gjort til en frivillig sag. I Berlin var der i 1875 i eet kvartal anmeldt 3000 børn, der ikke blev døbt, og 2000 ægteskaber, der kun blev indgået for de borgerlige myndigheder. Der var megen bitterhed, ikke blot blandt katolikkerne, men også blandt protestanter. »Med hele kulturkampen har man villet bekæmpe Rom og har ramt Wittenberg ", erklærede hofpræst Rud. Kögel, ${ }^{41}$ der sammen med kejserinde Augusta søgte at modarbejde Bismarck. En evangelisk kristen $i$ Tyskland skrev $i$ et brev: ${ }^{22}$ "Vor politik er realpolitik, materialistisk. Hvis den havde åndelige mål, så ville den forlængst have søgt sin hjælp mod romanismen dér, hvor den er at finde, $\mathrm{i}$ protestantismen, og ville ved at værne og pleje, vække og befri den evangeliske kirke have skabt den magt, som den kunne forlade sig på «. Man mente i store kredse, at kulturkampen kraftigt havde fremmet de kirkefjendske elementer $i$ befolkningen.

I hertugdømmerne blev loven mødt med stor uvilje af befolkningen. "Jeg er bange for, at vi går undergangen imøde«, sagde en fri- 
sisk fader. Der var steder, hvor det var umuligt for tilflyttere til et sogn at få bolig, når de ikke var kirkeligt viede. På Hallig Hooge følte man sig så rodfæstet i de overleverede skikke, at man tog loven humoristisk: "Du kanns nu bi'n Rathmann för füf Schilling trut werden, un wenn du ehr nich mehr liide magst, säggst du: geh man wedder na Huus na Mutter . $^{43}$

Selvfølgelig var der undtagelser, særlig i byerne, men også flere steder på landet. Det var for fristende at slippe for at betale de anordnede gebyrer ved de kirkelige handlinger. Hvor der var forstående menighedsrepræsentanter, traf de en ordning, så kirkekassen betalte disse gebyrer. Evt. kunne det ske, at de overtalte modvillige zgtepar til at lade sig kirkeligt vie.

Blandt de gejstlige er der en del, der med en vis stolthed beretter, at ingen i sognet forsmår de kirkelige handlinger, eller eventuelt, at efter, at et enkelt par ikke har ladet sig kirkeligt vie, vil dette nxppe gentage sig på grund af den uvilje, det har vakt. Men i almindelighed er presterne alligevel dybt bekymrede $i$ anledning af denne "ominøse « lov, »den lov, der bestemt ikke stammer fra urtysk ånd “, som en præst $i$ Langenhorn udtrykker sig. Selvom loven ikke har haft synlige virkninger, frygter mange dog, at forståelsen for de kirkelige handlingers værdi vil afstumpes. En pessimistisk præst mener, at det kun er vanens magt, der fär flertallet til stadig at holde fast ved de kirkelige handlinger. Det er ikke blot prester af den gamle skole, der ser skævt til loven. Præsten i Solt, H. C. Tamm, der som »fest protestantenfreundlich « ser det som målet, at kristendommen skal gennemsyre folkets kulturliv, frygter, at opfattelsen af religionen som en privatsag skal sive ned i de lavere lag og gøre "das Volkstum unkirchlicher und die Kirche unvolkstümlicher «.

Biskop Godt erkendte, at loven ikke var uden skadelig virkning i menighederne, men mente, at den på den anden side kunne få mange til at besinde sig på værdien af kirken og de kirkelige handlinger. Lejlighedsvis søgte han at belære og berolige. Han formanede menighederne til trofast at holde fast ved kirkens velsignelser. Han opmuntrede præsterne til at arbejde så meget ivrigere, til at undgå alt hierarkisk væsen og arbejde endnu mere i selvfornægtende kærlighed. I øvrigt mærkede han sig særligt, at loven gav anledning til, at nogle dansksindede $i$ de nordligste sogne søgte kirkelig vielse $i$ Danmark. 
Stort set var denne lov "sehr unbeliebt " hos befolkningen. Hos præsterne træffes adskillige gange ønsket om, at staten ville ændre sin liberale lovgivning og sætte grænser for den "systematiske forførelse af folket «.

Det var dønningerne fra kulturkampen, der gav ordet »liberal « en ond klang $\mathrm{i}$ de kirkelige ører, også $\mathrm{i}$ hertugdømmerne.

En dygtig præst, L. J. E. Clausen, i Sørup i Angel, skriver 1874: "Som overhovedet nu retningen mod det ydre og tilbøjeligheden til at overvurdere statsvæsenet er overvejende, således viser denne retning sig også her og er en hindring for det kirkelige og sædelige liv «. Han beretter om det "landøkonomiske Casino ", ${ }^{44}$ der i 1870 er oprettet dér på egnen til gensidig oplysning om landbrugets aktuelle spørgsmål og til fremme af det kommunale liv, at det tjener mere den gængse liberalisme end konservative tanker. "På kulturkæmpere er der naturligvis ingen mangel $\ll$. De højeste spidser indenfor befolkningen hxlder til liberalismen, de laveste trin til socialdemokratiet - kun mellem begge ligger den sunde midte, hvor kirken kan sxtte ind med sit arbejde.

Nogle synes med den liberale lovgivning at sigte til loven om erhvervsfrihed, der gjorde det lettere at oprette nye kroer og værtshuse. Værtshusene betegnes $\mathrm{i}$ godsdistrikterne som en kræftskade. I Gettorp i Dänischwold er der til 5800 indbyggere 9 danselokaler, 11 værtshuse og 5 keglebaner. I St. Peter i Ejdersted, hvor der er 5 værtshuse til en befolkning på knap 1000 indbyggere, spørger præsten: hvorfor forbyder regeringen ikke nye værtshuse? $\bowtie \mathrm{Ak}$, mangt et menneske bringer desværre! desværre! intet glædeligt hjem til sin ventende familie, så Gud må sig forbarme!« skriver den varmtfølende J. P. Blumensaat i Oversø.

"Der Zeitgeist «, tidsånden, er $\mathrm{i}$ øvrigt det ord, hvori de gejstlige sammenfatter al tidens gudloshed og materialisme.

Dette er ikke noget lokalt fænomen. I Tyskland stemples tiden efter kejserdømmets oprettelse som materialistisk. Den liberale teologiske professor Willibald Beyschlag i Halle skriver om denne tid: "Den teoretiske og den praktiske materialisme var, stærkere end før, blevet den beherskende magt, og forsåvidt man gik udover den, var det den stolte, selvtilfredse følelse af politisk magt og storhed, man vuggede sig $\mathrm{i} \ll{ }^{45}$

Med den teoretiske materialisme tænker Beyschlag vel på ind- 
flydelsen fra en filosof som Feuerbach eller fra de udbredte mere populære skrifter af Ludw. Büchner, Jac. Moleschott og Karl Vogt, der vil hævde, at alle »åndelige « fænomener har deres årsag i fysiologiske processer.

Og med den praktiske materialisme tænkes måske på kulturkampen, der, som nævnt, betragtes som udslag af en materialistisk politik, og på følgerne af hele den velstand, som de franske erstatningsbetalinger bragte ind over Tyskland $\mathrm{i}$ årene efter 1870, den sâkaldte "Gründerperiode«, hvor der daglig stiftedes nye aktieselskaber i Tyskland.

Ængsteligt ser prxster i Slesvig tidsåndens opløsende indflydelse. Clausen i Sørup, et sogn der ellers har ord for kirkeligt at være »Angels hjerte«, skriver 1877: „Mægtig banker vantroen på vor dor og begxrer at blive lukket ind «.

Sxrlig advares der mod den kirkefjendtlige presse. „O, den usalige presse! hvor megen ulykke bringer den ikke over ungdommelige gemytter! Hvordan skal der sættes grænser for pressens indflydelse? « Et sted beder præsten ved visitatsen, at biskoppen vil gøre de kirkexldste opmærksom på »Gemeindebote «s farlige karakter. En præst (M. P. Pomarius i Okholm) klager over vantroen i $\gg$ Itzehoer Nachrichten $*$ og Norddeutsche Zeitung , disse blade, der bliver »indsuget af de kloge og meddelt de uvidende «. Den bekymrede Peters i Osterhever klager over, at gennem "Die Gartenlaube ${ }^{46}$ og lignende blade trænger den hedenske materialisme, der mere eller mindre er de såkaldt dannedes livs- og verdensanskuelse, ind $i$ hans landmenighed. Det er en ren undtagelse, at den førnæunte "protestantenfreundliche « Tamm i Solt mener, at den tiltagende avislæsning plejer at løse den åndelige afstumpetheds bånd - altså også det religiøse.

Ikke blot pressen foruroliger $\mathrm{i}$ øvigt præsten $\mathrm{i} \varnothing_{\text {sterhever. Han }}$ ved at fortalle, at formanden for den stedlige "Volksbildungsverein " offentligt har sagt, at Kristus ikke mere er idealet på sædelighed $\mathrm{i}$ vort samfund.

Så vidt den teoretiske materialisme. Og med hensyn til den "praktiske«, så får den stigende velstand hos bønderne, der è en følge af »Gründertiden «s stigende priser, af mange præster skylden for en tiltagende materialisme og deraf følgende religiøs ligegyldighed. Det hedder sig også, at de gode tider ødelægger de patriarkal- 
ske forhold, hvilket undertiden viser sig deri, at tyendet ikke mere spiser sammen med husets egne folk.

1864 og de følgende begivenhedsrige år bragte ikke blot Slesvig ind $i$ en ny fase af nationalitetskampen. Slesvigs befolkning blev stillet ansigt til ansigt med en helt ny verden, en helt ny tid. Hvad der er sagt med henblik på den nye preussiske lovgivning, kan også siges med henblik på kirkelivet: „Den nye tid bankede på porten og blev uvenligt modtaget.$^{47}$

Forkortelser:

Beyschlag: Willibald Beyschlag: Aus meinem Leben. I-II, Halle. 1896/99.

K. u. S.: Schlesw.-Holst.-Lauenb. Kirchen und Schulblatt.

Nippold: $\quad$ Friedrich Nippold: Handbuch der neuesten Kirchengeschichte.

3. Auf. Bd. V. Geschichte der Kirche im deutschen Protestantismus. Leipzig. 1906.

Regling: Die Anfänge des Sozialismus in Schleswig Holstein. Quellen und Forschungen zur Geschichte Schleswig-Holsteins. Bd. 48. 1965.

Reinhardt: Georg Reinhardt: Preussen im Spiegel der öffentlichen Meinung Schleswig-Holsteins 1866-1870. Neumünster 1954.

Schr. d. Ver.: Schriften des Vereins für schlesw.-holst. Kirchengeschichte.

1. Reinhardt 4.

\section{NOTER}

2. Reinhardt 126.

3. Regling 127. 139.

4. Det oplyses desværre ikke, hvorledes man har fundet tilbage til disse ældgamle feltråb, der blev brugt under et slag ved Weinberg (i Württemberg) 1140, hvor kejser Konrad 3. af slægten Hohenstaufen og Henrik Loves farbroder af velfernes slagt kxmpede mod hinanden. Ordet $*$ Waiblingen kejserliges side med henblik på et hohenstaufisk arvegods af dette navn, beliggende $\mathrm{i}$ Württemberg.

5. Verhandlungen der ersten schlesw.-holst. Kirchenconferenz in Flensburg 13. Juli 1865. Itzehoe 1865.

6. Norddeutsche Zeitung, Flensburg 1864, 14., 15. og 17. juli. - B. Godt: Predigt am 13. Juli bei der Hauptversammlung des Schlesw.-Holst. Hauptvereins der Gustav-Adolf-Stiftung zu Schleswig. Kiel 1864.

7. Schr. d. Ver. 2. VI. 1917. 551. - Meddelelse om begivenhederne i Slesvig. Januar 1865. 93.

8. S. G. Simonsen: Friedenspredigt am 4. Decbr. 1864. Flensburg 1864. $\times$ Recht muss doch Recht bleiben * var som et motto for slesvig-holstenerne.

9. H. F. Neelsen: Predigt zur Friedensfeier am 4. Decbr. 1864.

10. Se note 5 .

11. K. u. S. $186620 / 10$ (s. 329 ). 
12. These 75 i Harms' theser fra 1817. Harms' ausg. Schriften, herausgegeben $\mathbf{v}$ P. Meinhold. Flensburg 1955. I. 209.

13. Nippold, 80 .

14. K. u. S. $186710 / 3$.

15. David Schenkel: Die gegenwärtige Lage der protestantischen Kirche in Preussen und Deutschland. Mannheim 1867. 42.

16. Evang. Kirchen-Zeitung 1866, 5. og 8. decbr.

17. Se note 14.

18. Otto v. Bismarck: Gedanken und Erinnerungen. - Bismarcks Briefe an seine Braut und Gattin 1906. - Friedrich Meinecke: Bismarcks Eintritt in den christlich-germanischen Kreis. Hist. Zeitschr. 1903. - Aage Friis: Bismarck. Kbh. 1909, sxrl. s. 95-106. - Otto Baumgarten: Bismarcks Stellung zu Religion und Kirche. (Die Klassiker der Religion Bd. 16). Göttingen 1922. Erich Marcks i Hist. Zeitschr. 1931. - Arnold Oskar Meyer: Bismarcks Glaube im Spiegel der Losungen und Lehrtexte. München 1933. - Leonhard von Muralt: Bismarcks Verantwortlichkeit. Göttingen 1955.

19. Beyschlag. II. 277.

20. K. u. S. $18676 / 10$.

21. Beyschlag. II. 282.

22. David Schenkel: Die gegenwärtige Lage der protestantischen Kirche in Preussen und Deutschland. Mannheim 1867. 42.

23. K. u. S. $186731 / 3$.

24. K. u. S. $18674 / 8$ (s. 257).

25. K. u. S. 1867 15/9.

26. K. u. S. $186710 / 11,186824 / 5,12 / 7,19 / 7$.

27. K. u. S. $18693 / 7$.

28. K. u. S. $18692 / 10$ (s. 432).

29. K. u. S. $186921 / 8$ (s. 345 ).

30. K. u. S. $186920 / 3$ (s. 114).

31. K. u. S. $186926 / 6$ (s. 237).

32. K. u. S. $186930 / 10$.

33. K. u. S. $18692 / 10$ (s. 426).

34. Kirche, Recht und Theologie, herausg. v. Walter Göbell. München 1867. I, s. 29, s. 288 (30/11 1901), II, s. 632 (27/5 1917).

35. Schr. d. Ver. 2. Reihe, Bd. $23 / 24,1967 / 68$, s. 32.

36. Wilh. Hasenclever, f. 1837 i Arnsberg (v. Ruhr), medlem af den tyske rigsdag 1874-81. Udgav fra 1876 sammen med Liebknecht bladet *Vorwärts*.

37. Otto Georg Reimer, f. 1841 i Hildesheim. Cigarhandler i Altona.

38. Regling.

39. K. u. S. $18697 / 8 \mathrm{f}$.

40. Frants Volkmar Reinhard Hansen, f. 1815 i Schilldorf, afskediget som prest i Keitum 1850, hofprest i Athen 1852-62, i Koburg 1863-64, prast ved Slesvig domkirke og provst for Gottorp provsti 1864 til sin død 1879.

41. Nippold 632.

42. Beyschlag. II. 359.

43. Du kan nu blive gift hos rådmanden for 5 Schilling, og når du ikke langere bryder dig om hende, siger du: gå bare hjem igen til mor.

44. O. C. Nerong: Das Kirchspiel Grundhof. 1895. 47.

45. Beyschlag. II. 432. 
46. Die Gartenlaube«, illustreret ugeblad, udgivet fra 1853 af Ernst Keil. Filosofen Friedrich Paulsen (f. 1846 i Langenhorn) læste det $i$ sin gymnasietid (186366) i Altona og lerte der, at meget tager sig anderledes ud for den lærde forskning end $i$ den overleverede trok. (Fr. Paulsen: Aus meinem Leben, Jena 1910. 139).

47. Reinhardt 78.

Efterskrift: Idet jeg takker Den Hielmstierne-Rosencroneske Stiftelse for støtte til en gennemgang af visitatsindberetningerne fra Slesvig stift $i$ årene 1864-85, har jeg foreløbig her sogt at trekke nogle karakteristiske hovedlinier op, som de tegner sig i det første tidsrum efter 1864. Jeg takker også arkiverne på Gottorp og i Ảbenrå såvel som Rigsarkivet for stor hjxlpsomhed under arbejdet. 